\title{
Tolerance, toxicity and transport of $\mathrm{Cd}$ and $\mathrm{Zn}$ in Populus trichocarpa
}

Article

Accepted Version

Creative Commons: Attribution-Noncommercial-No Derivative Works 4.0

De Oliveira, V. H. and Tibbett, M. (2018) Tolerance, toxicity and transport of $\mathrm{Cd}$ and $\mathrm{Zn}$ in Populus trichocarpa.

Environmental and Experimental Botany, 155. pp. 281-292. ISSN 0098-8472 doi:

https://doi.org/10.1016/j.envexpbot.2018.07.011 Available at https://centaur.reading.ac.uk/78404/

It is advisable to refer to the publisher's version if you intend to cite from the work. See Guidance on citing.

Published version at: http://dx.doi.org/10.1016/j.envexpbot.2018.07.011

To link to this article DOI: http://dx.doi.org/10.1016/j.envexpbot.2018.07.011

Publisher: Elsevier

All outputs in CentAUR are protected by Intellectual Property Rights law, including copyright law. Copyright and IPR is retained by the creators or other copyright holders. Terms and conditions for use of this material are defined in the End User Agreement.

\section{www.reading.ac.uk/centaur}

\section{CentAUR}

Central Archive at the University of Reading 
Reading's research outputs online 


\section{Original Article}

2

3

4

\section{Tolerance, toxicity and transport of $\mathrm{Cd}$ and $\mathrm{Zn}$ in Populus trichocarpa} Vinicius H. DE OLIVEIRA and Mark TIBBETT**

5

6

Centre for Agri-Environmental Research \& Soil Research Centre, School of Agriculture 7

Policy and Development, University of Reading, Berkshire, RG6 6AR, United Kingdom 8

9 Running title: Tolerance, toxicity and transport of $\mathrm{Cd}$ and $\mathrm{Zn}$ in poplar 10

11

For correspondence.E-mail: m.tibbett@ reading.ac.uk

12

13

14

15

16 


\section{Abstract}

Metal inputs to terrestrial ecosystems are of great concern due their toxicity to biota, especially for elements with no biological function such as cadmium. Fast-growing trees such as poplars may have potential in phytoremediation schemes. We assessed accumulation, metal partitioning, gene expression (Pt-HMA4) and overall tolerance to, and interaction between, cadmium $(\mathrm{Cd})$ and zinc ( $\mathrm{Zn})$ in Populus trichocarpa 'Trichobel'. We predicted that $\mathrm{Zn}$ would have an antagonistic effect in $\mathrm{Cd}$ accumulation and anticipated some level of tolerance to these metals. Poplars were grown in sandy substrate under different metal applications, ranging from 1 to $243 \mathrm{mg} \mathrm{kg}^{-1} \mathrm{Cd}$; or 30 to 7,290 $\mathrm{mg} \mathrm{kg}^{-1} \mathrm{Zn}$; and also two combined treatments: $27 \mathrm{mg} \mathrm{kg}^{-}$ ${ }^{1} \mathrm{Cd}$ with 90 or $270 \mathrm{mg} \mathrm{kg}^{-1} \mathrm{Zn}$. Growth parameters and metal contents in shoots and roots were determined. Transcriptional levels of the Pt-HMA4 gene were assessed in roots and leaves. $P$. trichocarpa showed a surprisingly high tolerance to $\mathrm{Cd}$, with root biomass being affected only at the highest doses applied. Metals accumulated mainly in roots (up to 6,537 $\mathrm{mg}$ $\mathrm{kg}^{-1} \mathrm{Cd}$ and 21,500 $\mathrm{mg} \mathrm{kg}^{-1} \mathrm{Zn}$ ), root-to-shoot translocation peaked at the $9 \mathrm{mg} \mathrm{kg}^{-1}$ dose for $\mathrm{Cd}(41 \%)$ and $90 \mathrm{mg} \mathrm{kg}^{-1}$ for $\mathrm{Zn}(40 \%)$. At high $\mathrm{Cd} / \mathrm{Zn}$ applications, expression of Pt-HMA4 in roots decreased significantly. Contrary to the initial presumption, $\mathrm{Zn}$ addition increased $\mathrm{Cd}$ uptake, reaching hyperaccumulator-like concentrations in shoots $\left(\geq 100 \mathrm{mg} \mathrm{kg}^{-1} \mathrm{Cd}\right)$. Differential root-to-shoot partitioning has a major role in Cd tolerance in P. trichocarpa; partly by down-regulating the Pt-HMA4 gene in roots. Zn addition promoted high $\mathrm{Cd}$ uptake without any detriment to plant growth. P. trichocarpa was tolerant to extreme $\mathrm{Cd}$ concentrations, offering a great potential to be used in phytoremediation techniques for stabilization/extraction of Cd from soils contaminated by both $\mathrm{Cd}$ and $\mathrm{Zn}$.

Key-words: gene expression, heavy metal, heavy metal transporter, metal partitioning, phytoremediation, phytotoxicity, poplar. 
1. Introduction

Cadmium $(\mathrm{Cd})$ is one of the most hazardous metals in the environment, ranked seventh in toxicity by the Agency for Toxic Substance and Disease Registry (ATSDR, 2017), it lacks any known biological function, being toxic to humans and other organisms at relatively low concentrations (Alloway 2013) and has a high mobility in soils (Lei et al., 2010). Cd is frequently found in zinc ( $\mathrm{Zn}$ ) bearing minerals (Alloway 2013) and, due to their similar geochemical characteristics $\mathrm{Zn}$ is often associated with $\mathrm{Cd}$ in soils (Kabata-Pendias and Pendias 2001), although not as toxic, high concentrations of $\mathrm{Zn}$ can be extremely harmful to biota. Plant exposure to $\mathrm{Cd}$ often leads to phytotoxicity depending on the concentration, plant genotype, soil characteristics and exposure time (Das et al., 1997; Benavides et al., 2005) mainly due to the fact that $\mathrm{Cd}$ has a chemical similarity to other essential elements, such as $\mathrm{Ca}$, Fe and particularly Zn (Clemens, 2006; Verbruggen et al., 2009). Growth impairment, biomass decrease, foliar necrosis and chlorosis are typical effects from $\mathrm{Cd}$ toxicity in plants ( $\mathrm{He}$ et al., 2017; Tran and Popova, 2013; Pál et al., 2006). Similar to Cd, Zn toxicity effects in plants include growth inhibition, leaf chlorosis and necrosis, oxidative stress, inhibition of protein functions and impairment of photosynthesis (Todeschini et al., 2011; Hasan et al., 2017). $\mathrm{Cd}^{2+}$ and $\mathrm{Zn}^{2+}$ are long known for being competing ions in the soil matrix due to their chemical similarities and same uptake pathways in plants (Clemens, 2006; Kirkham, 2006) in which Zn is often responsible for decreasing $\mathrm{Cd}$ uptake and even considered as a soil amendment to reduce Cd concentration in edible crops (Green et al., 2003; Garg and Kaur, 2013). However, it has been reported recently that Zn not always impact Cd accumulation (Green et al., 2017). Phytoremediation is the use of plants and their associated microorganisms for environmental decontamination (Pilon-Smits, 2005), from which phytoextraction is considered to be useful for inorganic contaminants (Marmiroli et al., 2006). It is an in situ technique that preserves soil structure and microbial activity, offering protection against erosion (Pulford and 
Watson, 2003; Guerra et al., 2011). Poplars (Populus sp.) are trees widely considered for

70 phytoextraction of several metals, such as $\mathrm{Cd}, \mathrm{Zn}, \mathrm{Pb}$ and $\mathrm{Cu}$ (Castiglione et al., 2009; Zacchini et al., 2009; Guerra et al., 2011; Dai et al., 2013; Luo et al., 2016), mainly due to their biomass production, deep root systems (Bhargava et al., 2012), tolerance to high metal concentrations and fast growth (Robinson et al., 2009). Populus species can also rapidly invade disturbed sites, reproduce asexually (Sebastiani et al., 2004; Hamberg et al., 2011) and are not a source of food for farm animals, reducing the risk of heavy metals entering the human food chain (Shim et al., 2013).

Metal tolerance and partitioning in plants are important features to be considered in phyoextraction (Luo et al., 2016), in which root-to-shoot translocation of Cd is regarded as a major factor in determining its toxicity thresholds in poplar (Durand et al., 2011). Several transmembrane proteins are involved in cation efflux from the cytoplasm, from which HMA4 (Heavy Metal ATPase 4), a common metal transporter from the P-type ATPase family, is known to play a role in the xylem-loading of metals (Hanikenne et al., 2008; Luo et al., 2016), affecting transport and accumulation in poplar (Adams et al., 2011). The HMA4 gene is considered to be key in $\mathrm{Zn}$ and $\mathrm{Cd}$ hyperaccumulation and also tolerance, which was previously verified in Arabidopsis thaliana (Mills et al., 2005), Noccaea caerulescens (Lochlainn et al., 2011) and transgenic Nicotiana tabacum plants (Grispen et al., 2011).

Populus trichocarpa (black cottonwood) is considered a model tree species (Bradshaw et al., 2000), with its genome already fully sequenced (Tuskan et al., 2006). However, little is known about heavy metal accumulation, toxicity and translocation in $P$. trichocarpa, most studies being mainly focused on other species from the Populus genus. The objectives of this work were to investigate (1) the effects of different concentrations of $\mathrm{Cd}$ and $\mathrm{Zn}$ on $P$. trichocarpa, (2) the accumulation and distribution of $\mathrm{Cd}$ and $\mathrm{Zn}$ within the plant and their effects on the expression of the metal transporter Pt-HMA4, and (3) the interactive effects 
94 between $\mathrm{Cd}$ and $\mathrm{Zn}$ in terms of phytotoxicity and metal distribution. We predicted that $\mathrm{Zn}$ could experiment.

2. Materials and Methods

\subsection{Plant material and pre-growth}

Cuttings (15 cm, two nodes) of Populus trichocarpa 'Trichobel' clones were rooted in sand for four weeks, and fertilised three times with $10 \mathrm{~mL}$ of a modified Long Ashton's solution (macronutrients: $\left(\mathrm{NH}_{4}\right)_{2} \mathrm{SO}_{4}(4 \mathrm{mM}), \mathrm{K}_{2} \mathrm{SO}_{4}(2 \mathrm{mM}), \mathrm{CaCl}_{2} \cdot 2 \mathrm{H}_{2} \mathrm{O}(3 \mathrm{mM}), \mathrm{MgSO}_{4} \cdot 7 \mathrm{H}_{2} \mathrm{O}(1.5$ $\mathrm{mM}), \mathrm{NaNO}_{3}(8 \mathrm{mM})$, FeEDTA $(0.1 \mathrm{mM})$; micronutrients: $\mathrm{H}_{3} \mathrm{BO}_{3}\left(2.86 \mathrm{mg} \mathrm{l}^{-1}\right), \mathrm{MnCl}_{2} \cdot 4 \mathrm{H}_{2} \mathrm{O}$ $\left(1.81 \mathrm{mg} \mathrm{l}^{-1}\right), \mathrm{CuSO}_{4} \cdot 5 \mathrm{H}_{2} \mathrm{O}\left(0.08 \mathrm{mg} \mathrm{l}^{-1}\right), \mathrm{NaMoO}_{4} \cdot 2 \mathrm{H}_{2} \mathrm{O}\left(0.025 \mathrm{mg} \mathrm{l}^{-1}\right), \mathrm{ZnSO}_{4} \cdot 7 \mathrm{H}_{2} \mathrm{O}(0.22$ mg $\left.\mathrm{l}^{-1}\right)$ ), according to Kariman et al., (2014) and $1 \mathrm{~mL}$ of a solution with $\mathrm{KH}_{2} \mathrm{PO}_{4}(1 \mathrm{mM})$. This clone is an intraspecific hybrid of Populus trichocarpa Torrey \& A. Gray ex Hook (Burgess et al., 2005).

All rooted cuttings were transplanted to plastic pots (without holes in the bottom) filled with $1 \mathrm{~kg}$ of substrate: $50 \mathrm{~g}$ vermiculite, $50 \mathrm{~g}$ peat moss and $900 \mathrm{~g}$ of sand $(\mathrm{pH} 6.9)$; one cutting per pot. Water holding capacity was maintained at $70 \%$ (300 $\mathrm{mL}$ of distilled water). The experiment was carried out in the glasshouse of the University of Reading, between December 2015 and February 2016. The temperature average recorded in the glasshouse during this period was $24.5^{\circ} \mathrm{C}( \pm 2.4)$, and artificial light was provided (18h/day). Poplar cuttings were obtained from AF Hill \& Son, Redditch, UK and were kept refrigerated at $4{ }^{\circ} \mathrm{C}$ until the 

assigned to one of the flour blocks. After one week, the final fertilisation was applied and all cuttings had their expanded leaves counted and stems measured from the node sprouting to the apex; a sample from the substrate was also taken for further analysis. All pots were spiked with either $\mathrm{Cd}$ or $\mathrm{Zn}$ solutions on the following day. $\mathrm{Cd}$ was added via $\mathrm{CdCl}_{2}$ stock solutions to make up six different concentrations in the pot substrate: $1,3,9,27,81$ and $243 \mathrm{mg} \mathrm{kg}^{-1}$

$124 \mathrm{Cd}$; $\mathrm{Zn}$ was added via $\mathrm{ZnSO}_{4}$ stock solutions, making up six different concentrations in the substrate: 30, 90, 270, 810, 2430 and $7290 \mathrm{mg} \mathrm{kg}^{-1} \mathrm{Zn}$. Two further treatments included both Cd and Zn: $27 \mathrm{mg} \mathrm{kg}^{-1} \mathrm{Cd}+90 \mathrm{mg} \mathrm{kg}^{-1} \mathrm{Zn}\left(\mathrm{Cd}_{27}+\mathrm{Zn}_{90}\right)$; and $27 \mathrm{mg} \mathrm{kg}{ }^{-1} \mathrm{Cd}+270 \mathrm{mg} \mathrm{kg}^{-1}$

$127 \mathrm{Zn}\left(\mathrm{Cd}_{27}+\mathrm{Zn}_{270}\right)$. Control had water only instead of the metal solutions, and all pots contained only one poplar cutting. Metals were added in a single dose and each treatment had four replicates arranged in blocks.

131 (gs, in mol m $\left.\mathrm{m}^{-2} \mathrm{~s}^{-1}\right)$ and transpiration rate $\left(\mathrm{mmol} \mathrm{m}^{-2} \mathrm{~s}^{-1}\right)$ using a portable infrared gas analyser

132 (LCi Portable Photosynthesis System). Plants were assessed in the glasshouse near solar

133 noon, under constant lighting. The two youngest expanded leaves of each plant were measured, except for the two highest $\mathrm{Zn}$ treatments (2430 and $7290 \mathrm{mg} \mathrm{kg}^{-1}$ ), which had too many dead leaves for analysis.

\subsection{Harvest and Phytotoxicity assessment}

138 After exposure to the toxic metals for five weeks, all plants had their living expanded 139 leaves counted and stems measured (before and after exposure to metals). Visual toxicity 140 symptoms recorded using the method described by Kariman et al., (2016), in which leaf areas

141 with symptoms such as discoloration, chlorosis or necrosis were ranked into 6 classes (0 to 5), 142 in which 0 represents no toxicity symptoms, 1 is up to $20 \%$ of symptomatic leaf tissue area 
143 (SLTA), 2 from 20 to $40 \%, 3$ from 40 to $60 \%, 4$ from 60 to $80 \%$ and 5 for symptomatic area

144 greater than $80 \%$. Two mature leaves were assessed for each plant, and the final scoring was

145 the average between those leaves.

146 Plants were then harvested and separated into roots, stems and leaves (initial cuttings were

147 not included in any analyses). Roots were washed thoroughly with tap water and immersed in

148 a $0.05 \mathrm{mM} \mathrm{CaCl}_{2}$ solution for 30 minutes to remove any surface adhering metals (Marmiroli et

$149 a l ., 2013)$, roots were rinsed with deionized water and scanned using the software WinRhizo®,

150 to determine the root length, diameter, root tips, surface area and volume. All plant parts were

151 dried separately in an oven at $70^{\circ} \mathrm{C}$ for seven days, then dry weight (DW) was determined. Soil

152 was air dried, sieved (2 $\mathrm{mm})$ and soil $\mathrm{pH}$ was determined in a water-soil suspension (2.5:1)

153 shook for $15 \mathrm{~min}$ at $120 \mathrm{rpm}$ (Rowell, 1994).

154

\subsection{Acid Digestion and Metal Determination}

Dried samples were ground and $50 \mathrm{mg}$ of plant material was digested for 8 hours in $5 \mathrm{~mL}$ of $70 \% \mathrm{HNO}_{3}\left(\geq 69 \%\right.$ TraceSELECT ${ }^{\circledR}$ for trace analysis) in closed glass vessels in heating blocks at $110^{\circ} \mathrm{C}$ (Huang et al., 2004). All digestions were performed in duplicates, and for quality control, a blank and a plant certified reference material (IAEA-359 cabbage leaves) were included. Digested extracts were then diluted in a solution of $2 \% \mathrm{HNO}_{3}+5 \mathrm{ppb} \mathrm{Rh}$, and filtered. The concentrations of $\mathrm{Cd}$ and $\mathrm{Zn}$ were determined by inductively coupled plasma mass spectrometry (Thermo Scientific ${ }^{\mathrm{TM}}$ iCAPTM $^{\mathrm{Q}}$ ICP-MS), using rhodium as an internal standard.

\subsection{Bioconcentration Factor, Translocation Factor and Tolerance Index}


168 concentrations within the plant tissue and in the soil or substrate; $T f$ is the ratio between the

169 metal concentrations in leaves and roots; and TI is the ratio between a parameter assess in

170 heavy metal treated plants and the control (Saraswat and Rai, 2009; Zacchini et al., 2009; Rafati

171 et al., 2011); see equations below, in which [M]: metal concentration; T: treated plants; C:

172 control plants.

173

$$
B C F=\frac{[M] \text { plant }}{[M] \text { soil }}
$$

175

$$
T f=\frac{[M] \text { leaf }}{[M] \text { root }} \times 100
$$

$$
T I \%=\frac{T}{C} \times 100
$$

179

\subsection{Pt-HMA4 expression in roots and leaves}

Poplar cuttings $(15 \mathrm{~cm})$ were grown inside a growth chamber $\left(23^{\circ} \mathrm{C} 16 \mathrm{~h} / 8 \mathrm{~h}\right.$ day/night $)$ in

a mixture of TerraGreen clay and sand $(1: 5, \mathrm{w} / \mathrm{w})$, one cutting per pot (photosynthetic photon

183 flux, $100 \mu \mathrm{mol} \mathrm{m} \mathrm{m}^{-2}$ ). All plants were fertilised weekly for the first three weeks with $10 \mathrm{~mL}$

of a modified Long Ashton's solution, as described previously. Water holding capacity was always maintained at $70 \%$ with distilled water. After five weeks, pots were spiked daily with either $27 \mathrm{mg} \mathrm{kg}^{-1} \mathrm{Cd}$ (via $\mathrm{CdCl}_{2}$ solution) or $100 \mathrm{mg} \mathrm{kg}^{-1} \mathrm{Zn}$ (via $\mathrm{ZnSO}_{4}$ ) for three days amounting to total doses of $81 \mathrm{mg} \mathrm{kg}^{-1} \mathrm{Cd}$ for the $\mathrm{Cd}$ treatment and $300 \mathrm{mg} \mathrm{kg}^{-1} \mathrm{Zn}$ for the $\mathrm{Zn}$ treatment; Controls received deionized water instead of Cd or $\mathrm{Zn}$ solutions. All treatments had three replicates.

Plants were harvested eight weeks after contamination. The 9th leaf of each plant

191 (counting from the base of the stem) was sampled and immediately frozen in liquid nitrogen

192 for RNA extraction. Roots were washed with tap water and random sections $(2 \mathrm{~cm}$ from root tips) were sampled and frozen. 
Total RNA was extracted from approximately $100 \mathrm{~g}$ of fresh weight material (leaves or roots) macerated in liquid nitrogen via TissueLyser II (Qiagen®). Extraction was performed by the CTAB method (Jaakola et al., 2001) and RNA pellets were purified with the RNeasy

197 Plant Mini kit (Qiagen, UK), including a DNAse treatment (Qiagen, UK) for 20 min. cDNA

198 synthesis was carried out using the SensiFAST cDNA synthesis kit (BIOLINE, UK) following 199 the manufacturer's instructions.

200 Specific primers were designed for Pt-HMA4, accession: XM_006381101, (F: 5, ACCAACGTTCTTATGCTTATTGC 3' / R: 5' CACTGGCCTTGTGGCTT 3') and Ubiquitin (UBQ), accession: XM_006373777 (F: 5' AGATGGCAGAACTTTGGCTGA 3' / R: 5' CGCCAAAGCCATCAAAGAAC 3') with the Primer-BLAST tool (Ye et al., 2012).

Nucleotide BLAST showed $71 \%$ between Pt-HMA4 and Arabidopsis thaliana ATPase, AtHMA4 (accession: NM_127468).

The qPCR reactions were performed in duplicates and at least twice for each sample using PowerUp ${ }^{\mathrm{TM}}$ SYBRGreen ${ }^{\mathrm{TM}}$ (Applied Biosystems, UK) with the following the parameters: 1 cycle of $2 \mathrm{~min}$ at $50^{\circ} \mathrm{C}$ followed by $2 \mathrm{~min}$ at $95^{\circ} \mathrm{C}$ (DNA polymerase activation), then 40 cycles of $95^{\circ} \mathrm{C}$ for 3 seconds (denaturation) and $60^{\circ} \mathrm{C}$ for 30 seconds (annealing/extension). The qPCR run, data collection and analyses were performed using StepOne ${ }^{\mathrm{TM}}$ Real-Time PCR System

211 (Applied Biosystems). Results were analysed by the standard curve method, and gene 212 expression was normalised using $U B Q$ as the house keeping gene.

\subsection{Statistical Analyses}

Statistical analyses were performed for all parameters assessed using R software. Metal treatments were considered as categorical factors and therefore ANOVA was performed for

217 each parameter assessed $(\mathrm{p}<0.05)$. When significant differences were detected, a Tukey test $218(\mathrm{p}<0.05)$ was carried out to discriminate differences between treatments. Pearson correlation 
219 was also performed. Data was transformed when necessary (determined by Shapiro-Wilk 220 normality test and Levene's test, $\mathrm{p}<0.05$ ) to attain normal distribution and homoscedasticity,

221 in order to meet ANOVA and Pearson correlation assumptions (Zar, 2010). Transformation

222 was carried out mainly by two equations: $\log (\mathrm{x})$ or $\mathrm{x}^{2}$; root dry weight data from $\mathrm{Zn}$ treatments

223 were transformed by $\sqrt[3]{x}$ after a BoxCox plot. Data that could not be transformed to attain 224 normality (i.e. a few root morphology parameters), Kruskal-Wallis followed by a Dunn's test $(\mathrm{p}<0.05)$ were performed. A non-parametric correlation test (Spearman) was done for 14 different variables to verify possible monotonic relationships and only significant $r_{s}$ values $(p$ $<0.05)$ were reported.

\section{Results}

\subsection{Growth, biomass production and transpiration rate}

Both Cd and Zn caused toxicity in P. trichocarpa plants after only five weeks of exposure, and the visual effects are evident in shoots and roots (Fig. 1 and 2), especially in $\mathrm{Zn}$ treatments. P. trichocarpa exhibited a considerable tolerance to Cd toxicity, and negative effects were significantly different from control only at the extreme concentration of $243 \mathrm{mg} \mathrm{kg}^{-1}$, except for leaf biomass, which was also affected at $81 \mathrm{mg} \mathrm{kg}^{-1} \mathrm{Cd}$. Nonetheless, the total biomass produced (leaves + stems + roots) was similar in all Cd treatments except for the highest dose of $243 \mathrm{mg} \mathrm{kg}^{-1} \mathrm{Cd}$ (Table 1). Zn toxic effects were detected at the lowest dose applied, of 30 $\mathrm{mg} \mathrm{kg}^{-1}$, which reduced leaf and shoot biomass (Table 1), although root biomass was unaffected in this treatment. Zn concentrations from 30 to $270 \mathrm{mg} \mathrm{kg}^{-1}$ caused comparable toxicity in $P$. trichocarpa, as seen in the total plant biomass produced, but further toxicity was observed at

241 higher concentrations. 

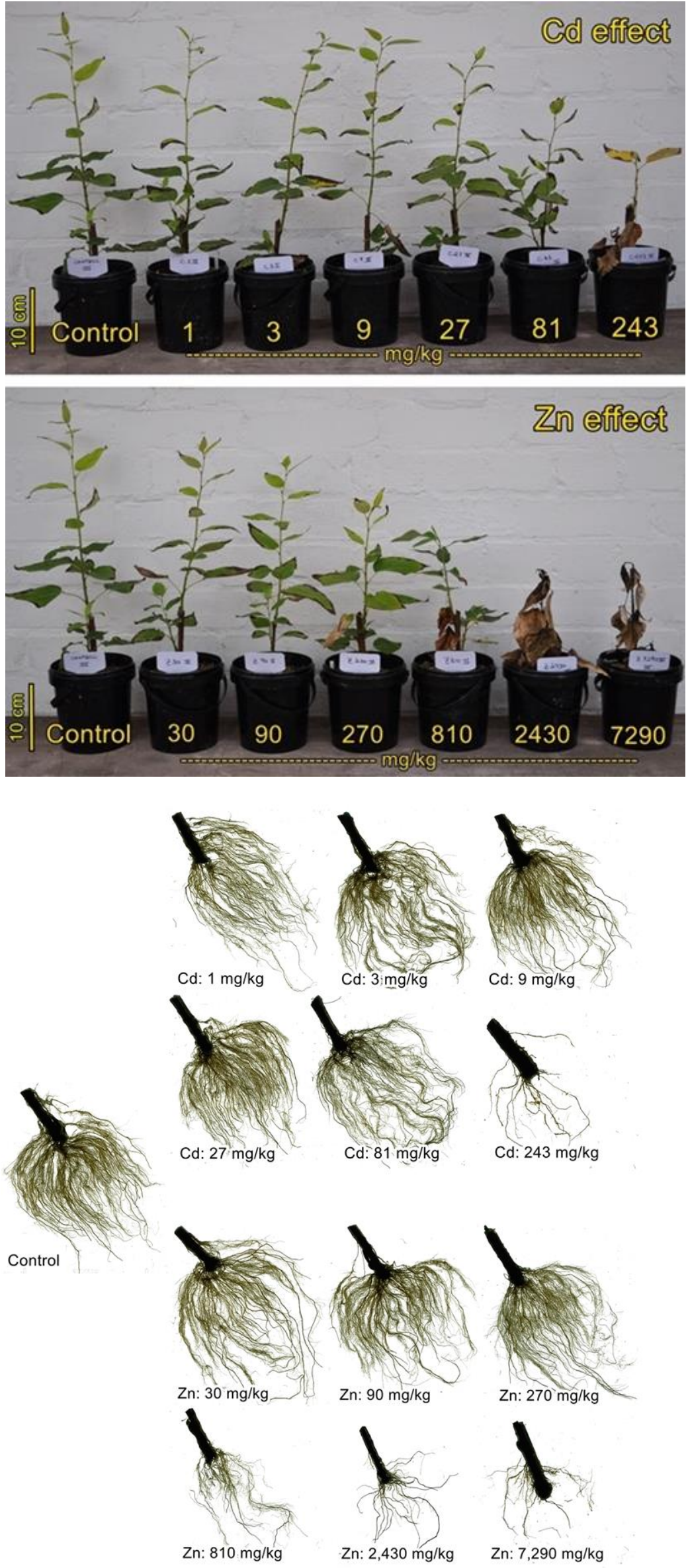

Fig. 1 - Phytotoxic effects of $\mathrm{Cd}$ and $\mathrm{Zn}$ in Populus trichocarpa at different soil concentrations, after five weeks of exposure.

Fig. 2 - Root scans of

Populus trichocarpa exposed to different $\mathrm{Cd}$ and $\mathrm{Zn}$ concentrations during five weeks. Images were used for length, area, volume and diameter analyses. 
Table 1. Dry biomass production, resulting $\mathrm{pH}$ and translocation index (TI) of $P$. trichocarpa exposed to different $\mathrm{Cd}$ or $\mathrm{Zn}$ concentrations during five weeks.

\begin{tabular}{|c|c|c|c|c|c|c|}
\hline \multirow{2}{*}{$\begin{array}{c}\text { Metal } \\
\left(\mathrm{mg} \mathrm{kg}^{-1}\right)\end{array}$} & \multicolumn{3}{|c|}{ Dry biomass (g) } & \multirow[t]{2}{*}{ Final $\mathrm{pH}$} & \multicolumn{2}{|c|}{ TI $(\%)$} \\
\hline & Leaves & Stems & Roots & & Leaves & Roots \\
\hline \multicolumn{7}{|l|}{ Cadmium } \\
\hline Control & $1.9 \pm 0.1 \mathrm{a}$ & $0.9 \pm 0.1 \mathrm{a}$ & $0.4 \pm 0.1 \mathrm{a}$ & $6.3 \mathrm{a}$ & 100 & 100 \\
\hline 1 & $1.9 \pm 0.1 \mathrm{a}$ & $0.9 \pm 0.1 \mathrm{a}$ & $0.4 \pm 0.1 \mathrm{a}$ & $6.2 \mathrm{ab}$ & 107 & 102 \\
\hline 3 & $1.7 \pm 0.1 \mathrm{ab}$ & $0.7 \pm 0.1 \mathrm{a}$ & $0.4 \pm 0.1 \mathrm{a}$ & $6.2 \mathrm{ab}$ & 96 & 93 \\
\hline 9 & $1.5 \pm 0.1 \mathrm{ab}$ & $0.6 \pm 0.1 \mathrm{a}$ & $0.3 \pm 0.0 \mathrm{a}$ & $6.2 \mathrm{ab}$ & 78 & 79 \\
\hline 27 & $1.7 \pm 0.1 \mathrm{ab}$ & $0.8 \pm 0.1 \mathrm{a}$ & $0.4 \pm 0.0 \mathrm{a}$ & $6.1 \mathrm{ab}$ & 94 & 92 \\
\hline 81 & $1.4 \pm 0.1 \mathrm{~b}$ & $0.6 \pm 0.1 \mathrm{a}$ & $0.3 \pm 0.0 \mathrm{a}$ & $6.2 \mathrm{ab}$ & 75 & 74 \\
\hline 243 & $0.5 \pm 0.1 \mathrm{c}$ & $0.2 \pm 0.0 \mathrm{~b}$ & $0.1 \pm 0.0 \mathrm{~b}$ & $6.0 \mathrm{~b}$ & 9 & 28 \\
\hline \multicolumn{7}{|l|}{ Zinc } \\
\hline Control & $2.0 \pm 0.0 \mathrm{a}$ & $0.9 \pm 0.0 \mathrm{a}$ & $0.5 \pm 0.0 \mathrm{a}$ & $6.3 \mathrm{a}$ & 100 & 100 \\
\hline 30 & $1.6 \pm 0.1 \mathrm{~b}$ & $0.7 \pm 0.1 \mathrm{~b}$ & $0.4 \pm 0.1 \mathrm{a}$ & $6.3 \mathrm{a}$ & 83 & 80 \\
\hline 90 & $1.5 \pm 0.0 \mathrm{~b}$ & $0.6 \pm 0.0 \mathrm{~b}$ & $0.4 \pm 0.0 \mathrm{a}$ & $6.3 \mathrm{a}$ & 86 & 76 \\
\hline 270 & $1.4 \pm 0.1 \mathrm{~b}$ & $0.6 \pm 0.0 \mathrm{~b}$ & $0.3 \pm 0.0 \mathrm{a}$ & $6.0 \mathrm{~b}$ & 62 & 68 \\
\hline 810 & $0.9 \pm 0.1 \mathrm{c}$ & $0.3 \pm 0.0 \mathrm{~b}$ & $0.1 \pm 0.0 \mathrm{~b}$ & $5.4 \mathrm{c}$ & 22 & 47 \\
\hline 2430 & $0.9 \pm 0.1 \mathrm{c}$ & $0.2 \pm 0.0 \mathrm{~b}$ & $0.1 \pm 0.0 \mathrm{~b}$ & $5.1 \mathrm{~d}$ & 11 & 47 \\
\hline 7290 & $0.9 \pm 0.1 \mathrm{c}$ & $0.2 \pm 0.0 \mathrm{~b}$ & $0.1 \pm 0.0 \mathrm{~b}$ & $4.8 \mathrm{~d}$ & 12 & 46 \\
\hline
\end{tabular}

Values are the mean $\pm \mathrm{SE}(\mathrm{Cd}$ treatments and $\mathrm{pH}, \mathrm{n}=4 ; \mathrm{Zn}$ treatments; $\mathrm{n}=3$ )

Significant differences among treatments (for each metal) are represented by different letters. Initial pH: 6.9;

Cd treatments and $\mathrm{pH}$ values: Tukey test: $p<0.05$;

Zn treatments: Dunn test, $p<0.05$.

Standard errors for the Final $\mathrm{pH}$ were $\leq 0.1$ for all treatments.

Foliar symptoms of phytotoxicity were more evident in $\mathrm{Cd}$ treatments than in $\mathrm{Zn}$ treatments, when compared to control at lower concentrations, 30 to $270 \mathrm{mg} \mathrm{kg}^{-1} \mathrm{Zn}$ (Fig. 3).

246 All treatments displayed marginal necrosis in the leaves assessed (older leaves), including the

247 control, but chlorosis and discoloration were present only in Cd-treated plants. Although 248 necrosis and chlorosis were both considered for the toxicity scoring, chlorosis were predominantly in Cd treatments. At the highest Zn concentrations (2430 and $7290 \mathrm{mg} \mathrm{kg}^{-1}$ ) all 

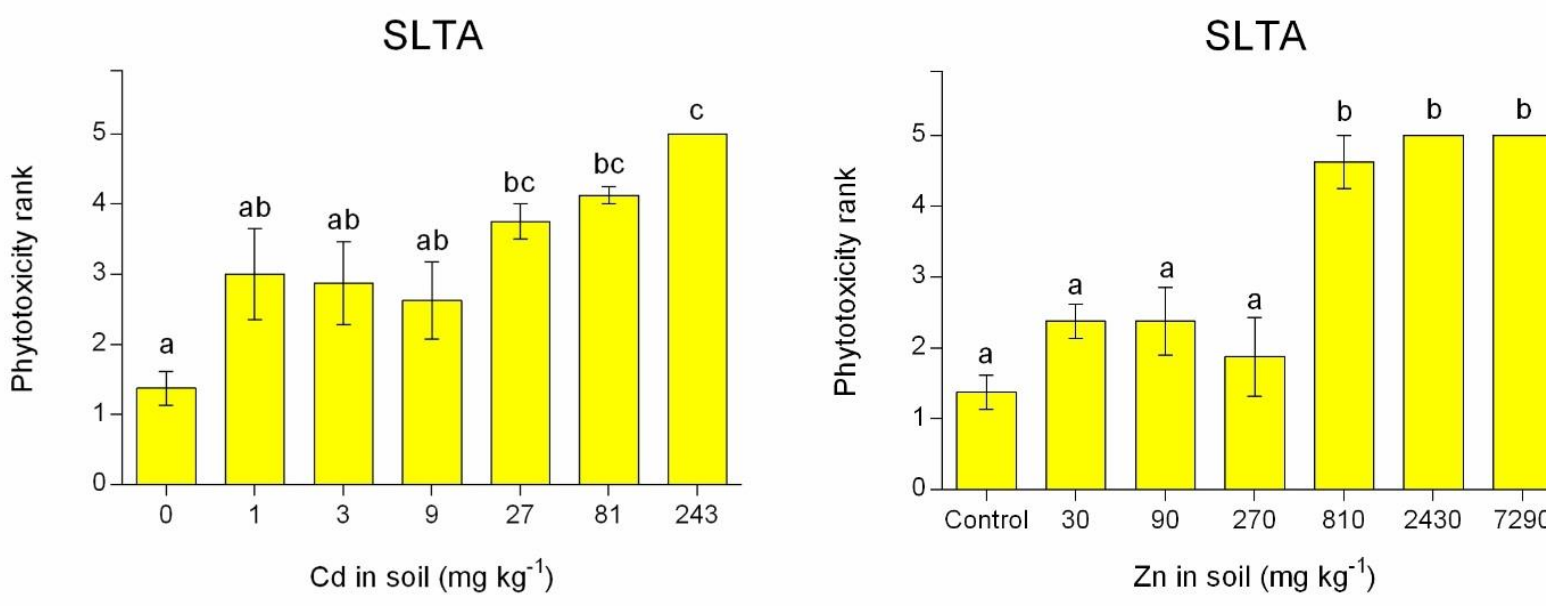

Fig. 3 - Toxicity ranks of $P$. trichocarpa exposed to different $\mathrm{Cd}$ and $\mathrm{Zn}$ concentrations. Symptomatic leaf tissue area (SLTA) was assessed visually and scored from 0 to 5 (each score represent $20 \%$ of leaf area). Significant differences are represented by different letters by Tukey test $(p<0.05)$ in Cd treatments and Dunn's test $(p<0.05)$ in $\mathrm{Zn}$ treatments.

Root scanning allowed the determination of root total length, area, volume and diameter for P. trichocarpa grown in different $\mathrm{Cd}$ and $\mathrm{Zn}$ concentrations. Results for root morphology parameters, leaf transpiration and stomatal conductance can be found in Table S1. Roots under Cd treatments displayed a similar response as the other parameters assessed, with evident toxicity effects only at the highest concentration of $243 \mathrm{mg} \mathrm{kg}^{-1}$. In the case of $\mathrm{Zn}$, length, area and volume reduction of roots was caused mainly at $810 \mathrm{mg} \mathrm{kg}^{-1}$ or higher concentrations. As for the analyses of stomatal conductance (gs) and transpiration rate (E), there were no significant differences among $\mathrm{Zn}$ treatments (Control $-810 \mathrm{mg} \mathrm{kg}^{-1}$ ) or among Cd treatments, 261 except for the highest concentration of $243 \mathrm{mg} \mathrm{kg}^{-1}$, in which there was a reduction in the 262 transpiration rate (E) in comparison to the control, from 2.65 to $0.48 \mathrm{mmol} \mathrm{m}^{-2} \mathrm{~s}^{-1}$, and in 263 stomatal conductance (gs), from 0.084 to $0.008 \mathrm{~mol} \mathrm{~m}^{-2} \mathrm{~s}^{-1}$ (Tukey test, $\mathrm{p}=0.0009$ and $\mathrm{p}=$ 0.0004, respectively). 


\subsection{Cadmium and zinc uptake, accumulation and translocation}

Cd uptake in poplar roots increased almost exponentially and was at least 10 times the concentration applied in some treatments ( 1 to $9 \mathrm{mg} \mathrm{kg}^{-1} \mathrm{Cd}$ ) (Fig. 4). In leaves, an increasing uptake is observed only until the concentration of $9 \mathrm{mg} \mathrm{kg}^{-1} \mathrm{Cd}$, after which there is a plateau and $\mathrm{Cd}$ concentration is maintained around $50 \mathrm{mg} \mathrm{kg}^{-1}$ (Fig. 4). However, in the treatment with $243 \mathrm{mg} \mathrm{kg}^{-1}$, Cd accumulation surpasses the plateau concentration in more than 10 times (from an average of 45 to $681 \mathrm{mg} \mathrm{kg}^{-1}$ ). The bioconcentration factor (BCF) shows a decrease in $\mathrm{Cd}$ accumulation for both roots and leaves as concentrations in soil increases (Table 2), except at

274 the highest concentration which had a BCF of 47.6 in poplar roots (tissue concentration of $6,537 \mathrm{mg} \mathrm{kg}^{-1} \mathrm{Cd}$ ), suggesting a loss of regulation in $\mathrm{Cd}$ uptake and excessive metal accumulation (Fig. 4). Overall the concentration of $9 \mathrm{mg} \mathrm{kg}^{-1} \mathrm{Cd}$ appears to be the threshold in

Cd translocation from roots to shoots ( $\mathrm{T} f=41 \%$, the highest in this study), after which the ratio between root and leaf concentration was reduced almost by half $\left(\mathrm{T} f=26 \%\right.$ at $\left.27 \mathrm{mg} \mathrm{kg}^{-1} \mathrm{Cd}\right)$. At the applied dose of $81 \mathrm{mg} \mathrm{kg}^{-1} \mathrm{Cd}$, root biomass was not affected despite tissue concentrations reaching nearly $500 \mathrm{mg} \mathrm{kg}^{-1} \mathrm{Cd}$ (Table 1 and Fig. 4). Cadmium concentration, translocation factor (Tf: roots-to-leaves) and bioconcentration factor (BCF) can be found in Table S4.

Unlike with $\mathrm{Cd}, \mathrm{Zn}$ content in roots did not differ significantly at lower soil concentrations ( $\leq 90 \mathrm{mg} \mathrm{kg}^{-1}$ ), increasing only after $270 \mathrm{mg} \mathrm{kg}^{-1} \mathrm{Zn}$ (Fig. 4). Zn content in leaves was a direct result of the concentration applied, although only a slight increase was observed between treatments of 810 and $2430 \mathrm{mg} \mathrm{kg}^{-1} \mathrm{Zn}$. 

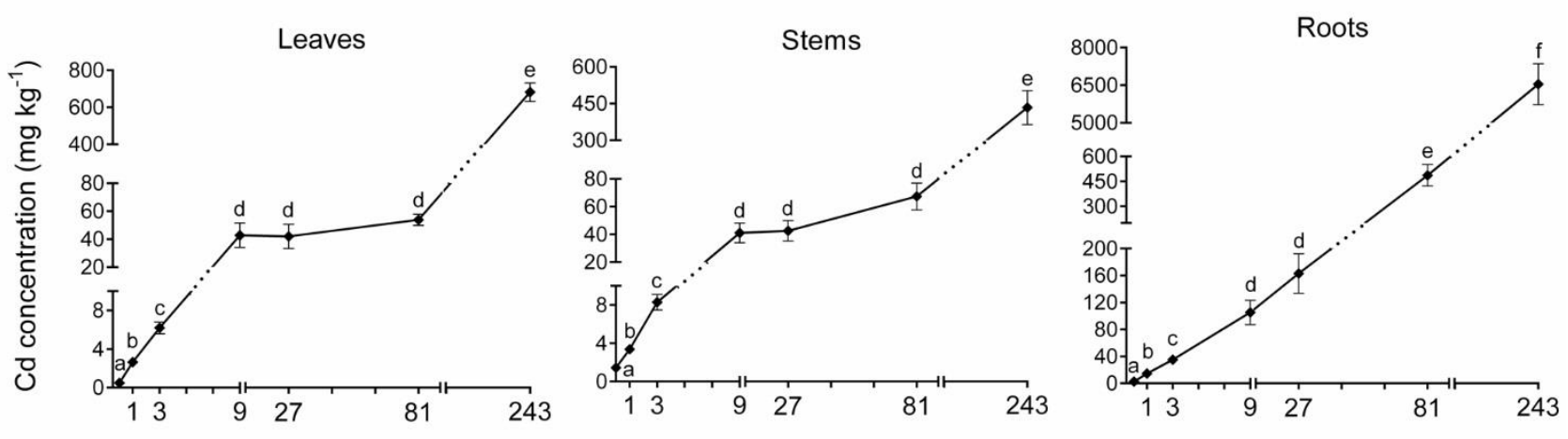

Cd applied $\left(\mathrm{mg} \mathrm{kg}^{-1}\right)$
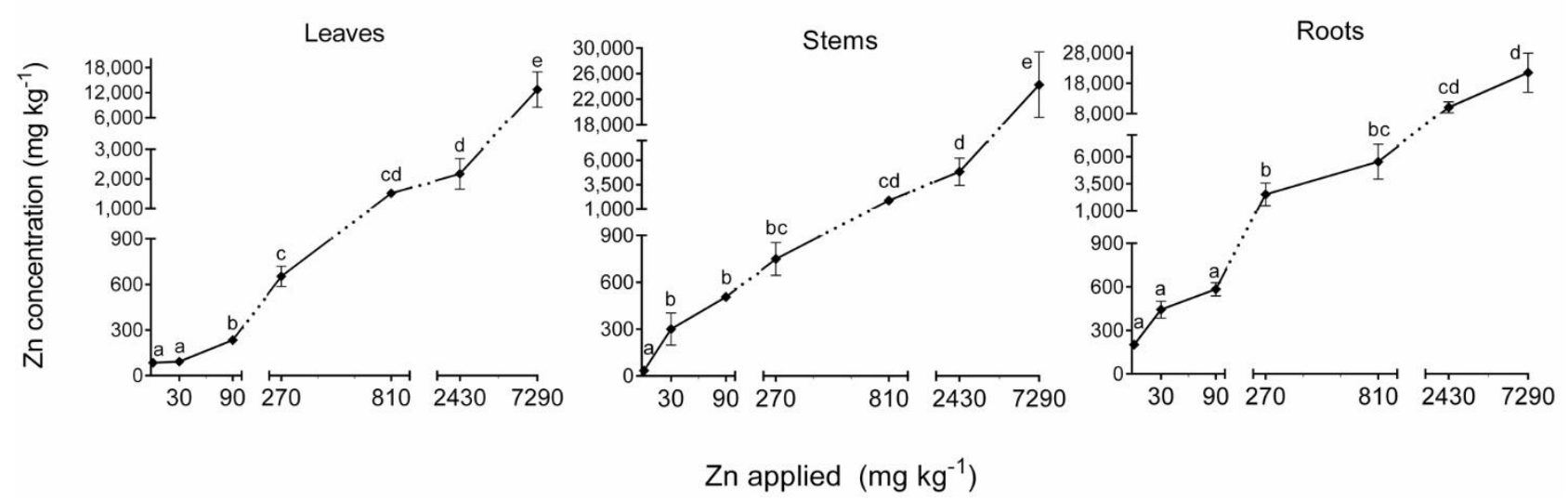

Fig. 4 - $\mathrm{Cd}$ and $\mathrm{Zn}$ concentrations $\left(\mathrm{mg} \mathrm{kg}^{-1}\right.$ ) in leaves, stems and roots of Populus trichocarpa grown for five weeks in sandy substrate at different $\mathrm{Cd}$ or $\mathrm{Zn}$ doses. Error bars indicate standard error of the mean $(n=4)$. Different letters correspond to significant differences between doses applied $(\mathrm{Cd}$ : Tukey test, $p<0.05$; Zn: Dunn's test, $p<0.05)$. To better visualise the complete data, $\mathrm{x}$ axis was set in $\log$ scale and breaks were added to both axes. Dotted lines between plotted data indicate the position of axis breaks. All values are presented in Tables S4 and S5.

$\mathrm{Zn}$ accumulation in roots varied across all treatments, and the highest BCF was found at

$29230 \mathrm{mg} \mathrm{kg}^{-1}$, and lowest at $7290 \mathrm{mg} \mathrm{kg}^{-1}$ (Table 2), however at the latter, translocation of $\mathrm{Zn}$

293 from roots to leaves was the highest found in this study $(T f=59 \%)$. Considering the tolerance

294 indexes, $90 \mathrm{mg} \mathrm{kg}^{-1} \mathrm{Zn}$ was the threshold for toxicity in both poplar roots and shoots (Table 1).

295 Interestingly, this treatment showed a translocation factor of $40 \%$, nearly the same factor found

296 at the $\mathrm{Cd}$ threshold concentration of $9 \mathrm{mg} \mathrm{kg}^{-1}$. Zinc concentration, translocation factor (Tf:

297 roots-to-leaves) and bioconcentration factor (BCF) can be found in Table S5.

298 Cd concentration in leaves and roots had an inverse relationship with all other variables. 
299 Stomatal conductance (gs) and transpiration rates (E) had a lower correlation to almost all other

300 parameters assessed (especially root parameters), however both variables were highly

301 correlated $\left(r_{s}>0.70\right)$ to the number of leaves (NL) and shoot growth (SG) (Table S2). Overall

$302 \mathrm{Zn}$ treatments had a similar correlation among all the parameters assessed to Cd treatments

303 with almost no correlations between $\mathrm{E}$ and gs and other variables (Table S3).

Table 2. Total metal uptake, translocation factor (Tf: roots-to-leaves) and bioconcentration factor (BCF) in Populus trichocarpa 'Trichobel' grown for five weeks under different $\mathrm{Cd}$ and $\mathrm{Zn}$ doses.

\begin{tabular}{|c|c|c|c|c|}
\hline \multirow{2}{*}{$\begin{array}{c}\mathrm{Cd} \\
\left(\mathrm{mg} \mathrm{kg}^{-1}\right)\end{array}$} & \multirow{2}{*}{$\begin{array}{l}\text { Cd uptake } \\
\left(\mu \mathrm{g} \text { plant }^{-1}\right)\end{array}$} & \multirow{2}{*}{$\mathrm{T} f$} & \multicolumn{2}{|c|}{$\mathrm{BCF}$} \\
\hline & & & Leaf & Root \\
\hline Control & $3.2 \pm 0.3$ & 20 & --- & --- \\
\hline 1 & $14.8 \pm 3.1$ & 18 & 2.6 & 14.4 \\
\hline 3 & $31.0 \pm 5.2$ & 18 & 2.1 & 11.7 \\
\hline 9 & $119 \pm 11$ & 41 & 4.8 & 11.7 \\
\hline 27 & $167 \pm 22$ & 26 & 1.6 & 6.0 \\
\hline 81 & $267 \pm 52$ & 11 & 0.7 & 6.0 \\
\hline 243 & $629 \pm 157$ & 6 & 2.8 & 47.6 \\
\hline \multirow{2}{*}{$\begin{array}{c}\mathrm{Zn} \\
\left(\mathrm{mg} \mathrm{kg}^{-1}\right)\end{array}$} & \multirow{2}{*}{$\begin{array}{l}\text { Zn uptake } \\
\left(\mathrm{mg} \mathrm{plant}^{-1}\right)\end{array}$} & \multirow{2}{*}{$\mathrm{T} f$} & \multicolumn{2}{|c|}{$\mathrm{BCF}$} \\
\hline & & & Leaf & Root \\
\hline Control & $0.3 \pm 0.01$ & 33 & --- & --- \\
\hline 30 & $0.5 \pm 0.1$ & 21 & 3.1 & 14.8 \\
\hline 90 & $0.9 \pm 0.1$ & 40 & 2.6 & 6.5 \\
\hline 270 & $2.0 \pm 0.2$ & 26 & 2.4 & 9.3 \\
\hline 810 & $2.5 \pm 0.5$ & 27 & 1.9 & 6.9 \\
\hline 2,430 & $3.5 \pm 1.1$ & 22 & 0.9 & 4.2 \\
\hline 7,290 & $17.9 \pm 2.2$ & 59 & 1.7 & 2.9 \\
\hline
\end{tabular}

Values are the mean \pm SE $($ Cd treatments, $n=4 ; Z n$ treatments; $n=3)$

$T f=$ (leaf concentration / root concentration $) \times 100$.

$\mathrm{BCF}=$ plant tissue concentration / dosage added. 
Efficient amplifications of Pt-HMA4 (POPTR_0006s07650g) were obtained from the designed primers (product length: $130 \mathrm{bp}$ ). In the control, Pt-HMA4 expression was five times

310 higher in roots than in leaves ( $\mathrm{t}$-test, $\mathrm{p}=0.043$ ), but this variation between tissues were not

311 observed in contaminated treatments. Exposure to either $\mathrm{Cd}$ or $\mathrm{Zn}$ down-regulated Pt-HMA4

312 expression in roots by 2.9-fold and 2.6-fold respectively (Fig. 5). No differences in transcript

313 levels were found in leaves. Ubiquitin $(U B Q)$ was used for normalisation of HMA4 results due

314 to their homogeneous expression across treatments (Control, $\mathrm{Cd}$ and $\mathrm{Zn}$ ): ANOVA, $p=0.768$

315 (leaves) and $p=0.781$ (roots).

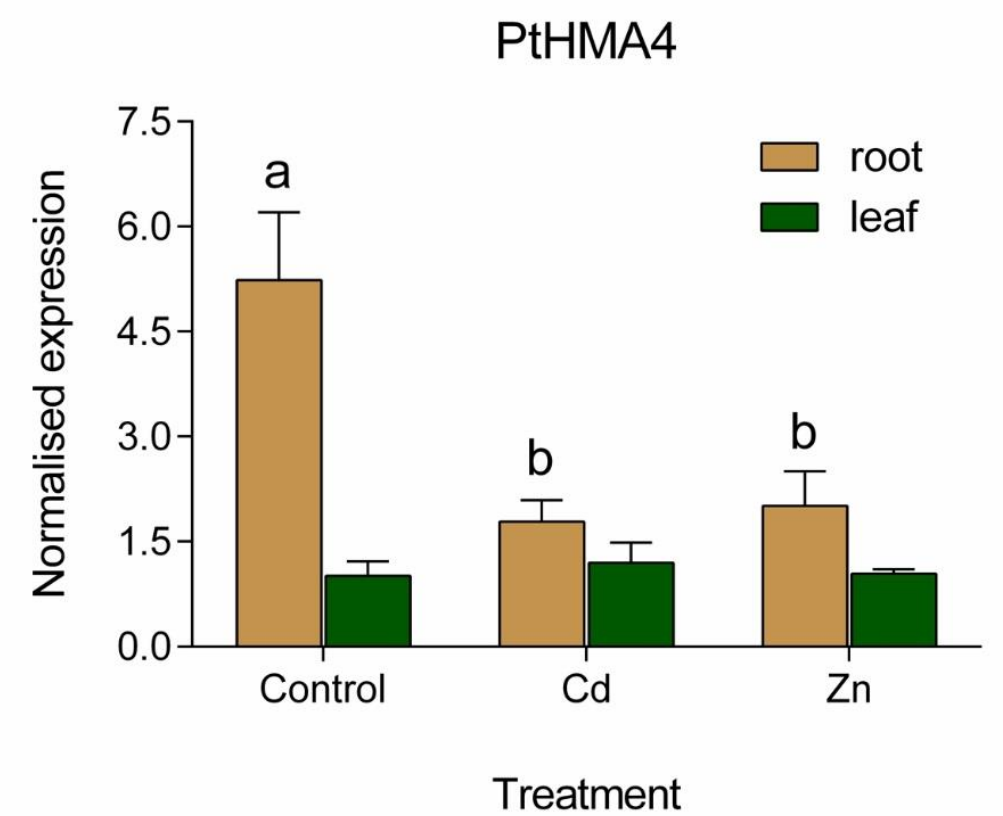

Fig. 5 - Transcript levels of the PtHMA4 gene in roots and leaves of P. trichocarpa after growing for eight weeks under Cd (81 mg kg$\left.{ }^{-1}\right)$ or $\mathrm{Zn}\left(300 \mathrm{mg} \mathrm{kg}^{-1}\right)$ stress, and without any metal addition (Control). The mRNA levels were quantified by real-time qPCR and normalised in relation to Ubiquitin (UBQ) expression; which had similar expression across treatments: ANOVA, $p=0.768$ (leaves) and $p=0.781$ (roots);. Different letters represent significant differences among treatments, determined by Tukey test after ANOVA $(p=0.0167)$. There were no differences among treatments in leaf tissues. 
Biomass production in treatments with combined metal applications did not significantly

322 change from the control nor their corresponded single metal treatments: $27 \mathrm{mg} \mathrm{kg}^{-1} \mathrm{Cd}$; or 90

323 and $270 \mathrm{mg} \mathrm{kg}^{-1} \mathrm{Zn}$. For instance, the Tolerance Index (TI) for total biomass was $100 \%$ for 27

$324+90 \mathrm{mg} \mathrm{kg}^{-1} \mathrm{Cd} \mathrm{Zn}$, and $83 \%$ for $27+270 \mathrm{mg} \mathrm{kg}^{-1} \mathrm{Cd} \mathrm{Zn}$; percentages are related to the non-

325 contaminated control. The same results were observed for root morphology, leaf transpiration

326 and stomatal conductance (data not shown). Despite exhibiting the same tolerance patterns, $\mathrm{Zn}$

327 addition increased $\mathrm{Cd}$ uptake, for instance, leaf concentration was of $123 \mathrm{mg} \mathrm{kg}^{-1}$ in $\mathrm{Cd}_{27}+$

$328 \mathrm{Zn}_{90}$, almost three times higher than the concentration found when $\mathrm{Cd}$ was added singly $\left(\mathrm{Cd}_{27}\right)$,

329 of $42 \mathrm{mg} \mathrm{kg}^{-1}$ (Fig. 6). Stems and roots also presented higher Cd contents after Zn addition,

330 regardless of $\mathrm{Zn}$ concentration. $\mathrm{Zn}$ uptake was not affected in the presence of $\mathrm{Cd}$ : leaf, stem

331 and root concentrations were not different from when $\mathrm{Zn}$ was added separately $\left(\mathrm{Zn}_{90}\right.$ and $\left.\mathrm{Zn}_{270}\right)$

332 (Fig. 6). 


\section{A}

$\mathrm{Cd}-\mathrm{Zn}$ interactions in metal uptake
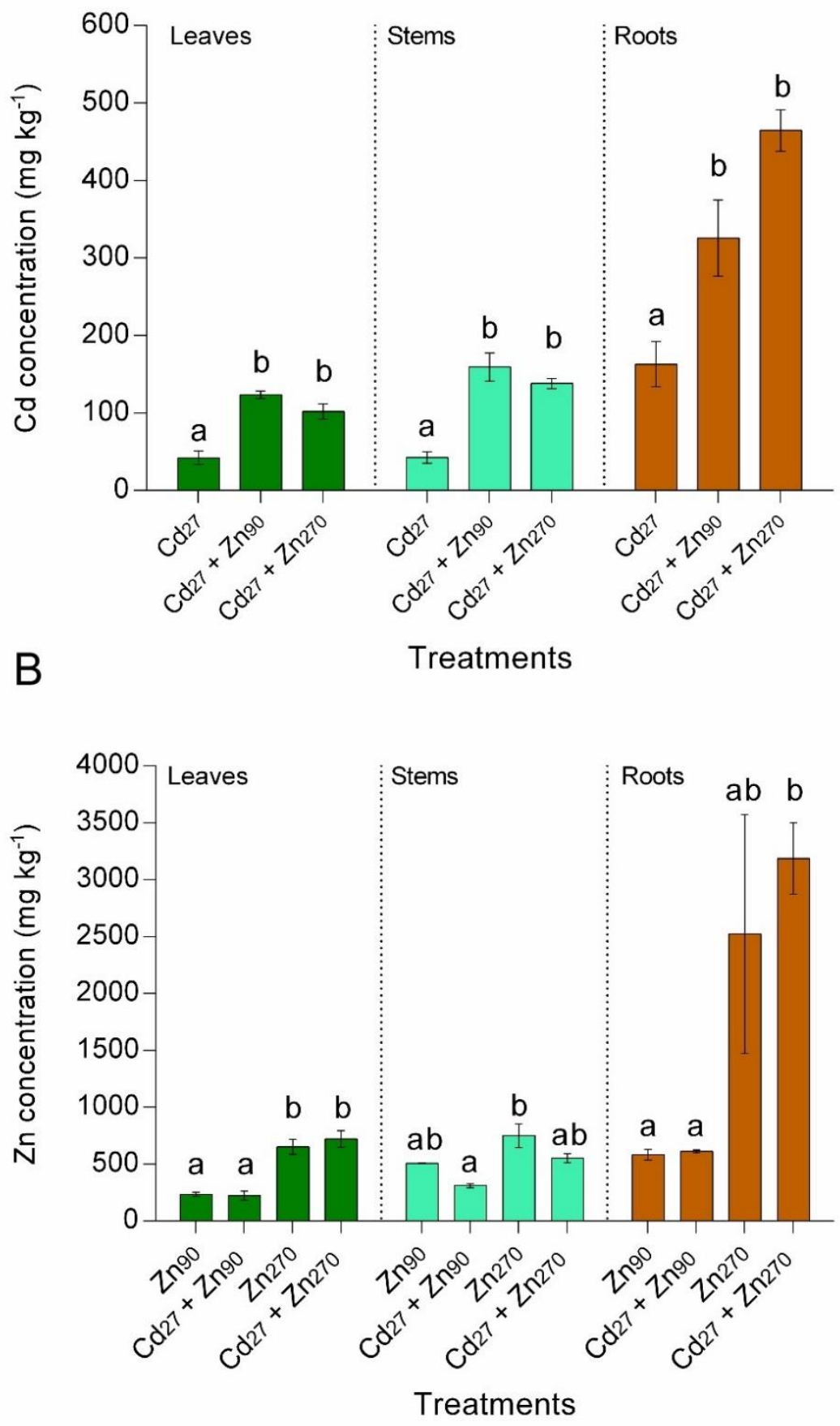

Fig. 6 - Concentrations of $\mathrm{Cd}(\mathrm{A})$ and $\mathrm{Zn}(\mathrm{B})$ in leaves, stems and roots of Populus trichocarpa exposed to different metal combinations: $27 \mathrm{mg} \mathrm{kg}^{-1} \mathrm{Cd}$, 90 or $270 \mathrm{mg} \mathrm{kg}^{-1} \mathrm{Zn}$. Different letters correspond to significant differences among treatments for the same plant tissue, Tukey test, $p<0.05$ (A) and Dunn's test, $p<0.05$ (B). 
4. Discussion

4.1 Cadmium accumulation, distribution and toxicity usually lose their function (Clemens, 2006; Verbruggen et al., 2009; Kupper and Andresen, 2016). Growth impairment is a typical effect from Cd toxicity (Pal et al., 2006), biomass decrease in roots and shoots are commonly reported (Tran and Popova, 2013), as well as foliar chlorosis and necrosis (Das et al., 1997). In the current experiment, despite P. trichocarpa showing symptoms of toxicity in leaves under $\mathrm{Cd}$ exposure, particularly at soil concentrations higher than $27 \mathrm{mg} \mathrm{kg}^{-1} \mathrm{Cd}$, loss of biomass was not evident in most of the treatments. Only at the highest concentration did all roots, stems and leaves present obvious toxic effects, indicating a remarkable tolerance to $\mathrm{Cd}$ in comparison to other published studies (Table 3). According to Audet and Charest (2008), plants from the Brassicaceae family, known for their high tolerance to metals, tend to maintain a constant biomass allocation to roots despite exposure to higher metal concentrations in soils, similar to that observed for poplars exposed to $\mathrm{Cd}$ in the present study, suggesting that in both cases metal partitioning plays a larger role in tolerance than does biomass plasticity.

Tolerance index (TI) is a good measure to compare different studies regarding metal toxicity. In this work, the tolerance index ranged from 107 to $75 \%$ in leaves across all $\mathrm{Cd}$ treatments, excluding the highest $\mathrm{Cd}$ concentration, which displayed a conspicuous toxicity. These values are within the bounds reported for poplars exposed to $\mathrm{Cd}$ concentrations lower than $30 \mathrm{mg} \mathrm{kg}^{-1}$ : TI of 90 to $78 \%$ in $P$ x canescens (Dai et al., 2013) and $91 \%$ in $P$. nigra (Gaudet et al., 2011). The most important mechanism for Cd tolerance in plants is the metal chelation and compartmentalization into the vacuoles (Sharma et al., 2016), especially via the phytochelatin (PC) pathway (Clemens, 2006). Expression of genes encoding metallothioneins 
360 (metal chelation) and heat shock proteins (proper protein folding) due to Cd exposure were 361 also associated with stress tolerance mechanisms in poplars (Hassinen et al., 2009; Hasan et al., 2017).

Cadmium accumulated mainly in the roots, as it is reported in most studies on poplars (Dos Santos Utmazian et al., 2007; Zacchini et al., 2009; Di Lonardo et al., 2011) or other plant species (Obata and Umebayashi, 1997; Green and Tibbett, 2008; Lux et al., 2011); while stems and leaves had generally the same concentrations. Despite much higher $\mathrm{Cd}$ accumulation, the roots of $P$. trichocarpa were as tolerant as its aboveground parts for most treatments (TI of $102-74 \%)$.

Cd concentration generally increases in leaves as a result of increasing soil or nutrient solution concentrations (Di Lonardo et al., 2011; Dai et al., 2013; Jun and Ling, 2012). Interestingly, $\mathrm{Cd}$ contents in both leaves and stems did not significantly change among the treatments of 9,27 and $81 \mathrm{mg} \mathrm{kg}^{-1} \mathrm{Cd}$, despite a significant increase in root concentration in the latter, exhibiting a plateau pattern in shoot accumulation. A similar pattern has been previously observed in P. leucoides (Jun and Ling 2012) and other plant species, such as barley (Green et al., 2006) and radish (Hamon et al., 1999), however this is generally uncommon in Populus species. This plateau concentration in shoots may be the main mechanism behind the tolerance observed even at high $\mathrm{Cd}$ doses. Root-to-leaf translocation decreased drastically from the treatments of 9 to $81 \mathrm{mg} \mathrm{kg}^{-1} \mathrm{Cd}$, which suggests two different strategies for this plant to cope with metal toxicity depending of the substrate concentration: one associated with hyperaccumulating plants (high translocation) and the other with woody plants (low translocation) at low and high Cd doses, respectively. 
Table 3. Reports of $\mathrm{Cd}$ and $\mathrm{Zn}$ toxicity in poplar trees. For comparison, all units for the metal concentrations were converted to $\mathrm{mg} \mathrm{kg}^{-1}$ for soils or other solid substrates, or $\mathrm{mg} \mathrm{L}^{-1}$, in the case of experiments using nutrient solution ('nutr. sol.') in hydroponic systems. The 'Phytotoxicity' column corresponds to the plant parameters most affected by metal toxicity. Lowest adverse observed effect concentration (LOAEC) shows the lowest $\mathrm{Cd}$ or $\mathrm{Zn}$ concentration to significantly cause toxicity (in some cases data was extracted from figures). The letter ' $\mathrm{x}$ ' corresponds to cases in which no toxicity was detected.

\begin{tabular}{|c|c|c|c|c|c|}
\hline Populus species & Growth substrate & Metal concentration & Phytotoxicity & LOAEC & Reference \\
\hline \multirow{9}{*}{ P. alba } & soil & $3.53 \mathrm{Cd}$ & $\mathrm{x}$ & $\mathrm{x}$ & 1 \\
\hline & nutr. sol. & $\begin{array}{c}0-130 \mathrm{Zn} \\
0-30 \mathrm{Cd}\end{array}$ & root biomass & $65 \mathrm{Zn}$ & 2 \\
\hline & soil & $950 \mathrm{Zn}+1,300 \mathrm{Cu}$ & overall biomass & $\begin{array}{c}950 \mathrm{Zn} \\
1,300 \mathrm{Cu}\end{array}$ & 3 \\
\hline & soil & $950 \mathrm{Zn}+1,300 \mathrm{Cu}$ & $\mathrm{x}$ & $\mathrm{x}$ & 4 \\
\hline & soil & $300 \mathrm{Zn}$ & overall biomass & $300 \mathrm{Zn}$ & 5 \\
\hline & nutr. sol. & $32-260 \mathrm{Zn}$ & root length & $130 \mathrm{Zn}$ & 6 \\
\hline & nutr. sol. & $32-260 \mathrm{Zn}$ & foliar symptoms & $130 \mathrm{Zn}$ & 7 \\
\hline & soil & $0-160 \mathrm{Cd}$ & $\mathrm{x}$ & $\mathrm{x}$ & 8 \\
\hline & soil & $300 \mathrm{Zn}$ & overall biomass & $300 \mathrm{Zn}$ & 9 \\
\hline \multirow{8}{*}{ P. canescens } & sand + peat moss & $300 \mathrm{Zn}$ & $\mathrm{x}$ & $\mathrm{x}$ & 10 \\
\hline & sand + peat moss & $50 \mathrm{Cd}$ & shoot biomass & $50 \mathrm{Cd}$ & 10 \\
\hline & soil & $360 \mathrm{Cd}$ & overall biomass & $360 \mathrm{Cd}$ & 11 \\
\hline & soil & $265 \mathrm{Zn}$ & $\mathrm{x}$ & $\mathrm{x}$ & 11 \\
\hline & soil & $360 \mathrm{Cd}$ & $\begin{array}{l}\text { stem height, } \\
\text { photosynthesis }\end{array}$ & $360 \mathrm{Cd}$ & 12 \\
\hline & soil & $0-2500 \mathrm{Zn}$ & lethal & $500 \mathrm{Zn}$ & 13 \\
\hline & nutr. sol. & $5.6 \mathrm{Cd}$ & chlorophyll & $5.6 \mathrm{Cd}$ & 14 \\
\hline & nutr. sol. & $1.12-7.8 \mathrm{Cd}$ & overall biomass & $7.8 \mathrm{Cd}$ & 15 \\
\hline \multirow{2}{*}{ P. deltoides } & soil & $8.14 \mathrm{Cd}$ & photosynthesis & $8.14 \mathrm{Cd}$ & 16 \\
\hline & soil + waste & $10,300 \mathrm{Zn} ; 5.5 \mathrm{Cd}$ & $\mathrm{x}$ & $\mathrm{x}$ & 17 \\
\hline \multirow{6}{*}{ P. euramericana } & soil & $8.14 \mathrm{Cd}$ & photosynthesis & $8.14 \mathrm{Cd}$ & 16 \\
\hline & inert clay & $0-650 \mathrm{Zn}$ & overall biomass & $327 \mathrm{Zn}$ & 18 \\
\hline & inert clay & $0-650 \mathrm{Zn}$ & overall biomass & $327 \mathrm{Zn}$ & 19 \\
\hline & vermiculite & 65 and $650 \mathrm{Zn}$ & biomass, leaf area & $65 \mathrm{Zn}$ & 20 \\
\hline & nutr. sol. & $0,0.1$ and $11 \mathrm{Cd}^{*}$ & root biomass & $0.1 \mathrm{Cd}$ & 21 \\
\hline & soil + waste & $10,300 \mathrm{Zn} ; 5.5 \mathrm{Cd}$ & $\mathrm{x}$ & $\mathrm{x}$ & 17 \\
\hline
\end{tabular}


Table 3. Continued.

\begin{tabular}{|c|c|c|c|c|c|}
\hline Populus species & Growth medium & Metal concentration & Parameter affected & LOAEC & Reference \\
\hline \multirow{5}{*}{ P. nigra } & soil & $1,760 \mathrm{Zn} ; 32.7 \mathrm{Cd}$ & $\mathrm{x}$ & $\mathrm{x}$ & 22 \\
\hline & soil & $300 \mathrm{Zn}$ & $\begin{array}{l}\text { shoot height, root } \\
\text { biomass }\end{array}$ & $300 \mathrm{Zn}$ & 5 \\
\hline & nutr. sol. & $5.6 \mathrm{Cd}$ & leaf biomass & $5.6 \mathrm{Cd}$ & 23 \\
\hline & nutr. sol. & $5.6 \mathrm{Cd}$ & overall biomass & $5.6 \mathrm{Cd}$ & 24 \\
\hline & nutr. sol. & $5.6 \mathrm{Cd}$ & root length, leaf area & $5.6 \mathrm{Cd}$ & 25 \\
\hline P. pyramidalis & soil & $0-100 \mathrm{Cd}$ & leaf biomass & $25 \mathrm{Cd}$ & 26 \\
\hline \multirow{4}{*}{ P. tremula } & soil & $1,760 \mathrm{Zn} ; 32.7 \mathrm{Cd}$ & $\mathrm{x}$ & $\mathrm{x}$ & 22 \\
\hline & nutr. sol. & $2.24 \mathrm{Cd}$ & overall biomass & $2.24 \mathrm{Cd}$ & 27 \\
\hline & nutr. sol. & $2.24 \mathrm{Cd}$ & shoot growth & $2.24 \mathrm{Cd}$ & 28 \\
\hline & soil & 3,000 Zn & $\mathrm{x}$ & $\mathrm{x}$ & 29 \\
\hline \multirow{3}{*}{ P. trichocarpa } & nutr. sol. & $5.6 \mathrm{Cd}$ & $\mathrm{x}$ & $\mathrm{x}$ & 25 \\
\hline & sand + vermic. & $0-243 \mathrm{Cd}$ & leaf biomass & $81 \mathrm{Cd}$ & $\begin{array}{l}\text { current } \\
\text { study }\end{array}$ \\
\hline & sand + vermic. & $0-7,290 \mathrm{Zn}$ & leaf, stem biomass & $30 \mathrm{Zn}$ & $\begin{array}{l}\text { current } \\
\text { study }\end{array}$ \\
\hline Populus sp. & soil & $\begin{array}{l}60-486 \mathrm{Zn} \\
0.05-1.6 \mathrm{Cd}\end{array}$ & $\mathrm{x}$ & $\mathrm{x}$ & 30 \\
\hline
\end{tabular}

[1] Ciadamidaro et al., 2014; [2] Di Lonardo et al., 2011; [3] Cicatelli et al., 2010; [4] Cicatelli et al., 2012; [5] Lingua et al., 2008; [6] Castiglione et al., 2007; [7] Franchin et al., 2007; [8] Rafati et al., 2011; [9] Todeschini et al., 2011; [10] Durand et al., 2011; [11] Durand et al., 2010a; [12] Durand et al., 2010b; [13] Langer et al., 2009; [14] He et al., 2011; [15] Dai et al., 2013; [16] Pajevic et al., 2009; [17] Sebastiani et al., 2004; [18] Di Baccio et al., 2005; [19] Di Baccio et al., 2009; [20] Di Baccio et al., 2010; [21] Lukovic et al., 2012; [22] Dos Santos Utmazian and Wenzel 2007; [23] Gaudet et al., 2011; [24] Iori et al., 2016; [25] Zacchini et al., 2009; [26] Hu et al., 2014; [27] Kieffer et al., 2009; [28] Sergeant et al., 2014; [29] Brunner et al., 2008; [30] Laureysens et al., 2004. * - Cd solutions re-applied weekly for a total of six weeks. to be a common mechanism of hyperaccumulators, in which the metal is detoxified by chelation, vacuole storage and rapidly translocation to shoots via the xylem (Tran and Popova,

390 2013). However, at $81 \mathrm{~kg} \mathrm{~kg}^{-1}$, there is a much higher Cd uptake in roots, which is a reflection

391 of the non-specific mechanisms by which Cd enters the plant system (Lux et al., 2011), thus in order to avoid toxicity in the photosynthetic apparatus, there is a limited transport of $\mathrm{Cd}$ to the

393 shoots ( $\mathrm{T} f: 11 \%)$. Restricting root-to-shoot translocation is a strategy typical of woody species

394 that may contribute to metal tolerance (Arduini et al., 1996) since the first important barrier 
against Cd toxicity is the immobilization in cell walls in roots (Sanita di Toppi and Gabbrielli, 1999). Lower translocation of Cd to shoots can be due to different mechanisms, such as downregulation of transporter proteins (i. e. heavy metal ATPases and ABC transporters) responsible for Cd loading in the xylem or increasing production of metal chelators (Lux et al., 2011). Lignification of cortical cells, sclerenchyma walls and vascular tissues can also be triggered by

400 Cd (Luković et al., 2012; Kupper and Andresen, 2016; Tylova et al., 2017), which may contribute to the thickening of the Casparian bands in the root apex (Schreiber et al., 1999; White, 2001) where high influx of $\mathrm{Cd}^{2+}$ occurs (He et al., 2011).

\subsection{Zn accumulation, distribution and toxicity}

Phytotoxic effects of $\mathrm{Zn}$ in plants is characterised by growth inhibition, leaf chlorosis and necrosis, oxidative stress, impairment of photosynthesis, degradation of mitochondria and chloroplasts (Todeschini et al., 2011) and, in general, Zn concentration in leaves above $300 \mathrm{mg}$ $\mathrm{kg}^{-1}$ induces visible toxicity symptoms (Marschner, 1995). Although there were no differences from control in terms of foliar symptoms at lower $\mathrm{Zn}$ doses applied $\left(\leq 270 \mathrm{mg} \mathrm{kg}^{-1} \mathrm{Zn}\right), P$. trichocarpa had significantly less leaf and stem biomasses even at the lowest dose of $30 \mathrm{mg}$

$411 \mathrm{~kg}^{-1}$, considered to be a sub-lethal concentration $\left(<65 \mathrm{mg} \mathrm{kg}^{-1}\right)$ (Romeo et al., 2014). It should

412 be noted that in our experiment the metal solutions were applied in a single pulse, in which a 413 rapid uptake could have occurred in these plants immediately after contamination and may 414 have impaired plant growth due to salinity or osmotic stress (Polle et al., 2013). Recent studies 415 have classified poplars as being sensitive to moderately sensitive to salinity stress (Mirck and 416 Zalesny, 2015). Moreover, high cation additions ( $\geq 270 \mathrm{mg} \mathrm{kg}^{-1} \mathrm{Zn}$; or $\left.243 \mathrm{mg} \mathrm{kg}^{-1} \mathrm{Cd}\right)$ 417 significantly decreased the substrate $\mathrm{pH}$, especially at extreme $\mathrm{Zn}$ concentrations (2430 and $4187290 \mathrm{mg} \mathrm{kg}^{-1}$ ), thus it is evident that this acidification could have led to an acute toxicity by 419 enhancing $\mathrm{Zn}^{2+}$ availability in the rhizosphere (Alloway, 2008). 

no effects from $130 \mathrm{mg} \mathrm{L}^{-1}$ on shoot biomass of three different $P$. alba varieties in vitro,

422 although root biomass in one case decreased by $85 \%$ at only $65 \mathrm{mg} \mathrm{L}^{-1}$. In our study, the shoots of $P$. trichocarpa were more sensitive to $\mathrm{Zn}$ than the roots, which only presented biomass loss at higher concentrations ( $\geq 810 \mathrm{mg} \mathrm{kg}^{-1} \mathrm{Zn}$ ). Root tolerance is an important feature in plants exposed to toxic metals, for it implies preservation of cell membranes selectivity properties, the initial step in uptake and xylem loading (Zacchini et al., 2009). Roots accumulated more $\mathrm{Zn}$ than the leaves, which is in accordance to some studies in poplars (Dos Santos Utmazian and Wenzel, 2007; Romeo et al., 2014), although other poplar species have demonstrated significantly higher Zn contents in leaves (Lingua et al., 2008; Castiglione et al., 2009; Cicatelli et al., 2010; Todeschini et al., 2011).

Although $\mathrm{Zn}$ doses applied were 10 times higher than $\mathrm{Cd}$, $\mathrm{Zn}$ translocation response (based on $\mathrm{T} f$ values) was somewhat analogous to the patterns seen in Cd-treated poplars. This suggests that $P$. trichocarpa adopts similar strategies for dealing with $\mathrm{Cd}$ and $\mathrm{Zn}$ toxicity by drastically decreasing metal translocation after a certain concentration threshold, in this case at $270 \mathrm{mg} \mathrm{kg}^{-1} \mathrm{Zn}$. Reducing $\mathrm{Zn}$ translocation as a protective effect was also seen in $P$. alba (Romeo et al., 2014) and P. nigra (Dos Santos Utmazian and Wenzel, 2007).

\subsection{Pt-HMA4 is down-regulated in roots under Cd and Zn stress}

The significant decrease in root-to-shoot translocation of $\mathrm{Cd}$ and $\mathrm{Zn}$ observed at the doses applied of $81 \mathrm{mg} \mathrm{kg}^{-1} \mathrm{Cd}$ and $270 \mathrm{mg} \mathrm{kg}^{-1} \mathrm{Zn}$, led us to investigate if the ATPase HMA4, which plays a pivotal role in metal detoxification and long distance transport in plants (Luo et al., 2016; Sarwar et al., 2017), could help explain such findings. Pt-HMA4 was expressed highly in roots, similar to what has been observed for other members of the HMA family in poplar, specifically around xylem vessels (Migeon et al., 2010). In A. halleri, exposure to Zn clearly 
445 showed an abundance of HMA4 transcripts in the root xylem adjacent to the pericycle layer, 446 which emphasises HMA4 involvement in xylem loading and justifies its high expression in 447 root tissues (Hanikenne et al., 2008).

Both $\mathrm{Cd}$ and $\mathrm{Zn}$ amendments resulted in down-regulation of Pt-HMA4 in poplar roots, which places this gene in the same subgroup of HMAs transporting $\mathrm{Zn} / \mathrm{Cd} / \mathrm{Co} / \mathrm{Pb}$ as found in A. thaliana (At-HMA1-4) and Oryza sativa (Os-HMA1-3) (Takahashi et al., 2012). Transport proteins such as HMA, can contribute to $\mathrm{Cd}$ efflux to the apoplast, sequestration into the vacuoles and directly affect Cd uptake and localisation (Iori et al., 2016; Hasan et al., 2017). Similarly, at high levels of $\mathrm{Zn}, P$. nigra down-regulated Pt-HMA4 expression in just 48 hours (Adams et al., 2011), but in the present study we showed that after eight weeks of exposure to $\mathrm{Cd}$ or $\mathrm{Zn}$ the expression of Pt-HMA4 was still much lower than uncontaminated control. Small variations in the expression of HMA4 in A. thaliana was demonstrated to have large effects in the Zn gradient in roots (Claus et al., 2013). Thus we can hypothesize that the regulation of PtHMA4 expression under $\mathrm{Cd}$ and $\mathrm{Zn}$ stress is one of the mechanisms by which $P$. trichocarpa maintains the metal partitioning pattern observed previously, in which a drastic decrease in translocation occurs as metal concentration reaches its toxicity threshold.

\subsection{Cd and Zn interactions in poplar}

Decrease in Cd uptake in plants due to elevated $\mathrm{Zn}$ supply has been commonly shown and is often associated with competitive interactions during root uptake, in which $\mathrm{Cd}$ is believed to enter the plant via transport processes inherent to Zn (Marschner, 1995; Hart et al., 2002; Garg and Kaur, 2013). The opposite can also be observed, for instance in wheat, a decrease in $\mathrm{Zn}$ translocation was attributed to competition with high Cd concentrations in soil (Green et al., 2010). We predicted similar outcomes, in which $\mathrm{Zn}$ would be preferentially taken up by the roots, therefore reducing $\mathrm{Cd}$ accumulation in the plant. However $\mathrm{Zn}$ had the opposite effect in 
P. trichocarpa under our experimental conditions and caused an overall increase in Cd uptake

471

474

475

476

477

478

479

480

481

482

483

484

485

486

487

488

489

490

491

492

493

494 and accumulation.

A pH decline in the substrate due to high cationic concentration $\left(\mathrm{Zn}^{2+}\right)$ may have played an important part in increasing Cd uptake, which is known for the inverse relationship with soil pH (Chuan et al., 1996; Smolders and Mertens, 2013). But substrate pH was unaffected by the addition of $90 \mathrm{mg} \mathrm{kg}^{-1} \mathrm{Zn}$ compared to when $\mathrm{Cd}$ was added singly (pH of 6.1 in both cases), yet it still lead to a significant increase in Cd concentrations in all plant parts: for instance $\mathrm{Cd}$ concentration in leaves increased from $42 \mathrm{mg} \mathrm{kg}^{-1}$ under single metal treatment to $123 \mathrm{mg} \mathrm{kg}^{-}$ ${ }^{1}$ under the combined treatment. Similar effect was observed in Nocceae caerulescens, in which combined treatments of $\mathrm{Zn}(500 \mu \mathrm{M})$ and $\mathrm{Cd}(200 \mu \mathrm{M})$ in hydroponic cultures resulted in increasing $\mathrm{Cd}^{2+}$ influx into root tissues and higher accumulation in shoots (Papoyan et al., 2007), and this response has been associated with hyperaccumulator phenotypes (Lasat et al., 1998; Papoyan and Kochian, 2004). Moreover, the hyperaccumulator Brassica juncea had an increase in $\mathrm{Cd}$ uptake after $\mathrm{Zn}$ addition, leading also to a higher tolerance in comparison to plants exposed to $\mathrm{Cd}$ and $\mathrm{Zn}$ separately (Kutrowska et al., 2017). In field conditions, positive correlation between $\mathrm{Zn}$ and $\mathrm{Cd}$ accumulation in shoots was also reported in Cacao trees (Arévalo-Gardini et al. 2017). Such response might be related to an up-regulation of genes encoding some metal transporters in roots triggered by the exposure to $\mathrm{Zn}^{2+}$, through which $\mathrm{Cd}^{2+}$ could have been actively transported. For instance, in Salix caprea the combined treatment of $\mathrm{Cd}$ and $\mathrm{Zn}$ induced the expression of transporters ZIP6 and HMA1 (Konlechner et al., 2013). Another reason for higher Cd uptake can be attributed to the direct competition between $\mathrm{Zn}$ and $\mathrm{Cd}$ for the soil adsorption sites ( $\mathrm{Lu}$ and $\mathrm{Xu} 2009$ ), for these elements have similar atomic characteristics and are both affected by electrostatic interactions (Moreira and Alleoni, 2010). Considering that the concentrations of $\mathrm{Zn}$ added were at least three times higher than $\mathrm{Cd}$, it is likely that $\mathrm{Zn}$ caused a displacement of $\mathrm{Cd}$ into the solution, increasing its 
availability for plant uptake.

Metal accumulation in P. trichocarpa varied depending on external metal contents and

497 also the plant's own regulatory system, which in some cases presented responses analogous to hyperaccumulator plants. Foliar concentration of $123 \mathrm{mg} \mathrm{kg}^{-1} \mathrm{Cd}$ is not high compared to well established Cd-hyperaccumulators such as $N$. caerulescens, that can accumulate more than

$5003000 \mathrm{mg} \mathrm{kg}^{-1} \mathrm{DW}$ (Papoyan et al., 2007). However Cd is naturally in plants at levels lower 501 than $1 \mathrm{mg} \mathrm{kg}^{-1}$ (Reeves, 2006) and, according to Baker et al. (2000) and He et al. (2017), concentrations higher than $100 \mathrm{mg} \mathrm{kg}^{-1} \mathrm{Cd}$ are exceptional and can be the threshold for recognizing a hyperaccumulator of $\mathrm{Cd}(0.01 \%$ of dry weight $)$.

$\mathrm{Zn}$ addition lead to higher $\mathrm{Cd}$ accumulation in leaves and stems, but this did not result in higher toxicity, suggesting that $\mathrm{Zn}$ also had a protective effect. According to Cherif et al. (2011), Zn addition can restore and enhance the functional activities of antioxidant enzymes such as superoxide dismutase, catalase and glutathione reductase that are suppressed by $\mathrm{Cd}$ toxicity. Concentration around $65 \mathrm{mg} \mathrm{L}^{-1} \mathrm{Zn}$ improved the photoprotective and antioxidant responses ( $\alpha$-Tocopherol and reduced glutathione) in two poplar clones in hydroponics

510 (Fernandez-Martinez et al., 2014). Overall, Zn can protect cells from damaging reactions caused by reactive oxygen species (ROS) and compete with Cd for binding sites in enzymes (SH groups) and membrane proteins (Cakmak, 2000; Cherif et al., 2011).

\section{Conclusions}

Cadmium and zinc toxicity affected growth and metal allocation in Populus trichocarpa 'Trichobel', in which Cd transport appears to be strongly regulated to some extent $(\leq 81 \mathrm{mg}$

$517 \mathrm{~kg}^{-1}$ ). Although shoot concentrations were not as high as found in extreme hyperaccumulator 518 plants, this variety of poplar has an exceptional tolerance to $\mathrm{Cd}$, especially considering that 519 phytotoxicity was mainly found in high and drastic Cd concentrations $\left(\geq 27 \mathrm{mg} \mathrm{kg}^{-1}\right)$, in which 
root integrity was barely affected. At lower Cd concentrations, $P$. trichocarpa displayed similar tolerance mechanisms and translocation patterns found in plants with hyperaccumulator phenotypes; in which metal partitioning appears to play a major role in Cd tolerance. Decrease in translocation at high metal concentrations was achieved partly by down-regulating the expression of Pt-HMA4 in roots. Zn promoted Cd uptake and shoot accumulation without compromising plant growth. Such results suggest that $P$. trichocarpa has the potential to survive, stabilise and extract $\mathrm{Cd}$ from soils in areas contaminated with both $\mathrm{Cd}$ and $\mathrm{Zn}$ and be a valid candidate for phytoremediation, especially in a short rotation coppice system. However, it is still necessary to better comprehend the interactions between $\mathrm{Cd}, \mathrm{Zn}$ and other toxic metals in this species, as well as consider its interactions with surrounding soil microbiota (e. g.

530 mycorrhizal symbiosis).

\section{Appendix A. Supplementary data}

533 Supplementary data can be found at: http://... and consist of the following tables. Table S1.

534 Root morphologic parameters, leaf transpiration (E) and stomatal conductance (gs) of Populus

535 trichocarpa exposed to different $\mathrm{Cd}$ and $\mathrm{Zn}$ concentrations for five weeks. Table S2. Spearman correlation $\left(\mathrm{r}_{\mathrm{s}}\right)$ matrix between 14 different variables from Populus trichocarpa grown under different Cd concentrations. Variables were considered monotonic correlated for $p<0.05$.

Table S3. Spearman correlation (rs) matrix between 14 different variables from Populus trichocarpa grown under different $\mathrm{Zn}$ concentrations. Variables were considered monotonic

540 correlated for $p<0.05$. Table S4. Cadmium concentration, total uptake, translocation factor

541 (Tf: roots-to-leaves) and bioconcentration factor (BCF) in Populus trichocarpa 'Trichobel'

542 grown for five weeks under different Cd doses. Table S5. Zinc concentration, total uptake,

543 translocation factor (Tf: roots-to-leaves) and bioconcentration factor (BCF) in Populus

544 trichocarpa 'Trichobel' grown for five weeks under different $\mathrm{Zn}$ doses. 
Acknowledgements

547 This work was supported by CAPES (Coordination for the Improvement of Higher Education

548 Personnel - Brazil) with the Science without Borders Programme [project: 13462-13-0].

Adams JP, Adeli A, Hsu CY. et al. 2011. Poplar maintains zinc homeostasis with heavy metal genes HMA4 and PCS1. Journal of Experimental Botany. 62: 3737-3752.

553

554

555

556

557

558

Alloway BJ. 2008. Zn in Soils and Crop Nutrition, 2nd edn. Brussels, Belgium and Paris: IZA and IFA.

Alloway BJ. 2013. Heavy Metals in Soils, 3rd edn. Netherlands: Springer.

Arduini I, Godbold DL, Onnis A. 1996. Cadmium and copper uptake and distribution in Mediterranean tree seedlings, Physiologia Plantarum 97: 111-117. doi: 10.1111/j.13993054.1996.tb00486.x.

Arévalo-Gardini E, Arévalo-Hernández CO, Baligar VC, He ZL. Heavy metal accumulation in leaves and beans of cacao (Theobroma cacao L.) in major cacao growing regions of Peru, Science of the Total Environment 605-606: 792-800. doi: 10.1016/j.scitotenv.2017.06.122.

ATSDR, Agency for Toxic Substances and Disease Registry. 2017. CERCLA Priority List of Hazardous Substances. https://www.atsdr.cdc.gov/spl/index.html . 24 Oct. 2017.

Audet P, Charest C. 2008. Allocation plasticity and plant-metal partitioning: Meta-analytical perspectives in phytoremediation, Environmental Pollution. 156: 290-296. doi: 10.1016/j.envpol.2008.02.010.

Baker AJM, McGrath SP, Reeves RD, Smith JAC. 2000. Metal hyperaccumulator plants: A review of the ecology and physiology of a biological resource for phytoremediation of metalpolluted soils. In: Terry N, Banuelos G, Vangrosveld J, eds. Phytoremediation of Contaminated Soil And Water. London: LewisPublisher, 85-107.

Benavides MP, Gallego SM, Tomaro ML. 2005. Cadmium toxicity in plants, Brazilian Journal of Plant Physiology. 17: 21-34.

Bhargava A, Carmona FF, Bhargava M, Srivastava S. 2012. Approaches for enhanced phytoextraction of heavy metals, Journal of Environmental Management. 105: 103-120.

Bradshaw H, Ceulemans R, Davis J, Stettler R. 2000. Emerging model systems in plant biology: poplar (Populus) as a model forest tree, Journal of Plant Growth Regulation. 19: 306313. https://doi.org/10.1007/s003440000030 
Brunner I, Luster J, Gunthardt-Goerg S. Frey B. 2008. Heavy metal accumulation and phytostabilisation potential of tree fine roots in a contaminated soil, Environmental Pollution. 152: 559-568.

Burgess PJ, Incoll LD, Corry DT, Beaton A, Hart BJ. 2005. Poplar (Populus spp) growth and crop yields in a silvoarable experiment at three lowland sites in England, Agroforestry Systems. 63: 157-169. doi.org/10.1007/s10457-004-7169-9.

Cakmak I. 2000. Possible roles of zinc in protecting plant cells from damage by reactive oxygen species, New Phytologist. 146: 185-205. doi: 10.1046/j.1469-8137.2000.00630.x.

600

601

602

603

604

605

606

607

608

609

610

611

612

613

614

615

616

617

618 concentrations reduce rooting capacity and alter metallothionein gene expression in white poplar (Populus alba L. cv. Villafranca), Chemosphere, 67: 1117-1126. doi: http://dx.doi.org/10.1016/j.chemosphere.2006.11.039.

Castiglione S, Todeschini V, Franchin C, et al. 2009. Clonal differences in survival capacity, copper and zinc accumulation, and correlation with leaf polyamine levels in poplar: a largescale field trial on heavily polluted soil, Environmental Pollution. 157: 2108-2117.

Cherif J, Mediouni C, Ammar WB, Jemal F. 2011. Interactions of zinc and cadmium toxicity in their effects on growth and in antioxidative systems in tomato plants (Solanum lycopersicum), Journal of Environmental Sciences. 23: 837-844. doi: 10.1016/S10010742(10)60415-9.

Chuan MC, Shu GY, Liu JC. 1996. Solubility of heavy metals in a contaminated soil: Effects of redox potential and $\mathrm{pH}$, Water, Air and Soil Pollution. 90: 543-556. doi: 10.1007/BF00282668.

Ciadamidaro L, Madejon P, Madejon E. 2014. Soil chemical and biochemical properties under Populus alba growing: Three years study in trace element contaminated soils, Applied Soil Ecology. 73: 26-33.

Cicatelli A, Lingua G, Todeschini V, Biondi S, Torrigiani P, Castiglione S. 2010. Arbuscular mycorrhizal fungi restore normal growth in a white poplar clone grown on heavy metal-contaminated soil, and this is associated with upregulation of foliar metallothionein and polyamine biosynthetic gene expression, Annals of Botany. 106: 791-802.

Cicatelli A, Lingua G, Todeschini V, Biondi S, Torrigiani P, Castiglione S. 2012. Arbuscular mycorrhizal fungi modulate the leaf transcriptome of a Populus alba L. clone grown on a zinc and copper-contaminated soil, Environmental and Experimental Botany. $\mathbf{7 5}$ : $25-35$.

Claus J, Bohmann A, Chavarria-Krauser A. 2013. Zinc uptake and radial transoirt ub roots of Arabidopsis thaliana: a modelling approach to understand accumulation. Annals of Botany. 112: 369-380.

Clemens S. 2006. Toxic metal accumulation, responses to exposure and mechanisms of tolerance in plants, Biochimie. 88: 1707-1719.

639 
Dai HP, Shan CJ, Jia GL. et al. 2013. Responses to cadmium tolerance, accumulation and translocation in Populus $\times$ canescens, Water, Air and Soil Pollution. 224: 1-9.

644

645

646

647

648

Das P, Samantaray S, Rout GR. 1997. Studies on cadmium toxicity in plants: a review, Environal Pollution. 98: 29-36.

Di Baccio D, Kopriva S, Sebastiani L, Rennenberg H. 2005. Does glutathione metabolism have a role in the defence of poplar against zinc excess?, New Phytologist. 167: 73-80.

Di Baccio D, Minnocci A, Sebastiani L. 2010. Leaf structural modifications in Populus x euramericana subjected to Zn excess, Biologia Plantarum. 54: 502-508.

Di Baccio D, Tognetti R, Minnocci A, Sebastiani L. 2009. Responses of the Populus x euramericana clone I-214 to excess zinc: Carbon assimilation, structural modifications, metal distribution and cellular localization, Environmental and Experimental Botany. 67: 153-163.

Di Lonardo S, Capuana M, Arnetoli M, Gabbrielli R, Gonnelli C. 2011. Exploring the metal phytoremediation potential of three Populus alba L. clones using an in vitro screening, Environmental Science and Pollution Research. 18: 82-90.

Dos Santos Utmazian MN, Wenzel WW. 2007. Cadmium and zinc accumulation in willow and poplar species grown on polluted soils, Journal of Plant Nutrition and Soil Science. 170: 265-272.

Dos Santos Utmazian MN, Wieshammer G, Vega R, Wenzel WW. 2007. Hydroponic screening for metal resistance and accumulation of cadmium and zinc in twenty clones of willows and poplars, Environmental Pollution. 148, 155-165. doi: http://dx.doi.org/10.1016/j.envpol.2006.10.045.

Durand TC, Baillif P, Alberic P, Carpin S, Label P, Hausman JF, Morabito D. 2011. Cadmium and zinc are differentially distributed in Populus tremula x P. alba exposed to metal excess, Plant Biosystems. 145: 397-405.

Durand TC, Hausman JF, Carpin S, Alberic P, Baillif P, Label P, Morabito D. 2010a. Zinc and cadmium effects on growth and ion distribution in Populus tremula $\mathrm{x}$ P. alba, Biologia Plantarum. 54: 191-194.

Durand TC, Sergeant K, Planchon S. et al. 2010b. Acute metal stress in Populus tremula X P. alba (717-1B4 genotybe): Leaf and cambial proteome changes induced by cadmium ${ }^{2+}$, Proteomics. 10: 349-368.

Fernandez-Martinez J, Zacchini M, Fernandez-Marin B, Garcia-Plazaola JI, Fleck I. 2014. Gasexchange, photo- and antioxidant protection, and metal accumulation in I-214 and Eridano Populus sp. clones subjected to elevated zinc concentrations, Environmental and Experimental Botany. 107: 144-153.

Franchin C, Fossati T, Pasquini E, Lingua G, Castiglione S, Torrigiani P, Biondi S. 2007. High concentrations of zinc and copper induce differential polyamine responses in micropropagated white poplar (Populus alba), Physiologia Plantarum. 130: 77-90. 
Garg N, Kaur H. 2013. Impact of cadmium-zinc interactions on metal uptake, translocation and yield in pigeonpea genotypes colonized by arbuscular mycorrhizal fungi, Journal of Plant Nutrition. 36: 67-90.

Gaudet M, Pietrini F, Beritognolo I. et al. 2011. Intraspecific variation of physiological and molecular response to cadmium stress in Populus nigra L., Tree Physiology. 31: 1309-1318.

Green CE, Chaney RL, Bouwkamp J. 2003. Interactions between cadmium uptake and phytotoxic levels of zinc in hard red spring wheat, Journal of Plant Nutrition. 26: 417-430. doi: 10.1081/PLN-120017144.

Green CE, Chaney RL, Bouwkamp J. 2017. Increased zinc supply does not inhibit cadmium accumulation by rice (Oryza sativa L.), Journal of Plant Nutrition. 40: 869-877. doi: 10.1080/01904167.2016.1262407

Green ID, Diaz A, Tibbett M. 2010. Factors affecting the concentration in seven-spotted ladybirds (Coccinella septempunctata $\mathrm{L}$.) of $\mathrm{Cd}$ and $\mathrm{Zn}$ transferred through the food chain, Environmental Pollution. 158: 135-141.

Green ID, Jeffries C, Diaz A, Tibbett M. 2006. Contrasting behaviour of cadmium and zinc in a soil-lant-arthropod system, Chemosphere. 61: 1115-1121.

Green ID, Tibbett M. 2008. Differential uptake, partitioning and transfer of $\mathrm{Cd}$ and $\mathrm{Zn}$ in the soil-pea plant-aphid system, Environmental Science \& Technology. 42: 450-455. doi: 10.1021/es071992c.

Grispen VMJ, Hakvoort HWJ, Bliek T, Verkleij JAC, Schat H. 2011. Combined expression of the Arabidopsis metallothionein MT2b and the heavy metal tranporting ATPase HMA4 enhances cadmium tolerance and the root to shoot translocation of cadmium and zinc in tobacco. Environmental and Experimental Botany. 72: 71-76.

Guerra F, Gainza F, Perez R, Zamudio F. 2011. Phytoremediation of heavy metals using poplars (Populus Spp): A glimpse of the plant responses to copper, cadmium and zinc stress, in: Golubev IA, ed. Handbook of Phytoremediation. New York: NOVA, 387-413.

\section{Hamberg L, Malmivaara-Lamsa M, Lofstrom I, Vartiamaki H, Valkonen S, Hantula J.} 2011. Sprouting of Populus tremula L. in spruce regeneration areas following alternative treatments, European Journal of Forest Research. 130: 99-106.

Hamon RE, Holm PE, Lorenz SE, McGrath SP, Christensen TH. 1999. Metal uptake by plants from sludge-amended soils: caution is required in the plateau interpretation, Plant and Soil. 216: 53-64.

Hanikenne M, Talke IN, Haydon MJ. et al. 2008. Evolution of metal hyperaccumulation required cis-regulatory changes and triplication of HMA4, Nature. 453: 391-395.

Hart J, Welch RM, Norvell WA, Kochian LV. 2002. Transport interactions between cadmium and zinc in roots of bread and durum wheat seedlings, Physiologia Plantarum. 116: 73-78. 
Hassinen V, Vallinkoski VM, Issakainen S, Tervahauta A, Karenlampi S, Servomaa K. 2009. Correlation of foliar $M T 2 b$ expression with $\mathrm{Cd}$ and $\mathrm{Zn}$ concentrations in hybrid aspen (Populus tremula $\mathrm{x}$ tremuloides) grown in contaminated soil. Environmental Pollution. 157: 922-930.

He J, Qin J, Long L. et al. 2011. Net cadmium flux and accumulation reveal tissue-specific oxidative stress and detoxification in Populus $\times$ canescens, Physiologia Plantarum. 143: 5063.

He S, Yang X, He Z, Baligar VC. 2017. Morphological and physiological responses of plants to cadmium toxicity: a review, Pedosphere. 27: 421-438. doi: 10.1016/S1002-0160(17)603394.

Hu Y, Nan Z, Jin C, Wang N, Luo H. 2014. Phytoextraction potential of poplar (Populus alba L. var. pyramidalis Bunge) from calcareous agricultural soils contaminated by cadmium, International Journal of Phytoremediation. 16: 482-495. doi: 10.1080/15226514.2013.798616.

Huang L, Bell RW, Dell B, Woodward J. 2004. Rapid nitric acid digestion of plant material with an open-vessel microwave system, Communications in Soil Science and Plant Analysis. 35: 427-440. doi: 10.1081/CSS-120029723.

Iori V, Gaudet M, Fabbrini, F. et al. 2016. Physiology and genetic architecture of traits associated with cadmium tolerance and accumulation in Populus nigra L., Trees. 30: 125-139.

Jaakola L, Pirtilla M, Halonen M, Hohtola A. 2001. Isolation of high quality RNA from Bilberry (Vaccinium myrtillus L.) fruit. Molecular Biotechnology. 19: 201-203.

Jun R, Ling T. 2012. Increase of Cd accumulation in five poplar (Populus L.) with different supply levels of Cd, International Journal of Phytoremediation. 14: 101-113. doi: 10.1080/15226514.2010.525564.

Kabata-Pendias A, Pendias H. 2001. Trace Elements In Soils And Plants, Florida: CRC press.

Kariman K, Barker SJ, Jost R, Finnegan PM, Tibbett M. 2014. A novel plant-fungus symbiosis benefits the host without forming mycorrhizal structures, New Phytologist. 201: $1413-1422$.

Kariman K, Barker SJ, Jost R, Finnegan PM, Tibbett M. 2016. Sensitivity of jarrah (Eucalyptus marginata) to phosphate, phosphite, and arsenate pulses as influenced by fungal symbiotic associations, Mycorrhiza. 26: 401-415. doi: 10.1007/s00572-015-0674-z.

Kieffer P, Planchon S, Oufir M. et al. 2009. Combining proteomics and metabolite analyses to unravel cadmium stress-response in poplar leaves, Journal of Proteome Research. 8: 400417.

Kirkham MB. 2006. Cadmium in plants on polluted soils: effects of soil factors, 
hyperaccumulation, and amendments, Geoderma. 137: 19-32.

Konlechner C, Turktas M, Langer I. et al. 2013. Expression of zinc and cadmium responsive genes in leaves of willow (Salix caprea L.) genotypes with different accumulation characteristics. Environmental Pollution. 178: 121-127.

Kupper H, Andresen E. 2016. Mechanisms of metal toxicity in plants, Metallomics. 8: 269285.

Kutrowska A, Malecka A, Piechalak A et al. 2017. Effects of binary metal combinations on zinc, copper, cadmium and lead uptake and distribution in Brassica juncea, Journal of Trace Elements in Medicine and Biology. 44: 32-39. doi: 10.1016/j.jtemb.2017.05.007.

Langer I, Krpata D, Fitz WJ, Wenzel WW, Schweiger PF. 2009. Zinc accumulation potential and toxicity threshold determined for a metal-accumulating Populus canescens clone in a dose-response study, Environmental Pollution. 157: 2871-2877. doi: http://dx.doi.org/10.1016/j.envpol.2009.04.003.

Lasat MM, Baker AJM, Kochian LV. 1998. Altered Zn compartmentation in the root symplasm and stimulated $\mathrm{Zn}$ absorption into the leaf as mechanisms involved in $\mathrm{Zn}$ hyperaccumulation in Thlaspi caerulescens, Plant Physiology. 118: 875-883.

Laureysens I, Blust R, De Temmerman L, Lemmens C, Ceulemans R. 2004. Clonal variation in heavy metal accumulation and biomass production in a poplar coppice culture: I. Seasonal variation in leaf, wood and bark concentrations, Environmental Pollution. 131: 485494.

Lei M, Zhang Y, Khan S, Qin P, Liao B. 2010. Pollution, fractionation, and mobility of Pb, $\mathrm{Cd}, \mathrm{Cu}$, and $\mathrm{Zn}$ in garden and paddy soils from a $\mathrm{Pb} / \mathrm{Zn}$ mining area, Environmental Monitoring and Assessment. 168: 215-222.

Lingua G, Franchin C, Todeschini V.et al. 2008. Arbuscular mycorrhizal fungi differentially affect the response to high zinc concentrations of two registered poplar clones, Environmental Pollution. 153: 137-147.

Lochlainn SO, Bowen HC, Fray RG. et al. 2011. Tandem quadruplication of HMA4 in the Zinc $(\mathrm{Zn})$ and Cadmium $(\mathrm{Cd})$ hyperaccumulator Noccaea caerulescens. PLOS One. 6: e17814. doi: 10.1371/journal.pone.0017814.

Lu SG, Xu QF. 2009. Competitive adsorption of $\mathrm{Cd}, \mathrm{Cu}, \mathrm{Pb}$ and $\mathrm{Zn}$ by different soils of Eastern China, Environmental Geology. 57: 685-693. doi: 10.1007/s00254-008-1347-4.

Luković J, Merkulov L, Pajevic S. et al. 2012. Quantitative assessment of effects of cadmium on the histological structure of poplar and willow leaves', Water, Air and Soil Pollution. 223: 2979-2993. doi: 10.1007/s11270-012-1081-0.

Luo ZB, He J, Polle A, Rennenberg H. 2016. Heavy metal accumulation and signal transduction in herbaceous and woody plants: Paving the way for enhancing phytoremediation efficiency, Biotechnology Advances. 34: 1131-1148. 
840 Lux A, Martinka M, Vaculik M, White PJ. 2011. Root responses to cadmium in the rhizosphere: a review, Journal of Experimental Botany. 62: 21-37. doi: 10.1093/jxb/erq281.

844 Marmiroli M, Imperiale D, Maestri E, Marmiroli N. 2013. The response of Populus spp. to cadmium stress: Chemical, morphological and proteomics study, Chemosphere. 93: 13331344.

Marmiroli N, Marmiroli M, Maestri E. 2006. Phytoremediation and phytotechnologies: a review for the present and the future. In: Twardowska I, Allen HE, Häggblom MM, Stefaniak S, eds. Soil and Water Pollution Monitoring, Protection and Remediation, NATO Science Series vol 69. Dordrecht: Springer, 403-416.

Marschner H. 1995. Mineral Nutrition of Higher Plants, 1st edn. London: Academic Press.

Migeon A, Blaudez D, Wilkins O. et al. 2010. Genome-wide analysis of plant metal transporters with an emphasis on poplar. Cellular and Molecular Life Sciences. 67: 3763-3784.

Mills RF, Francini A, Ferreira da Rocha PSC. et al. 2005. The plant $\mathrm{P}_{1 \mathrm{~B}}$-type ATPase AtHMA4 transports $\mathrm{Zn}$ and $\mathrm{Cd}$ and plays a role in detoxification of transition metals supplied at elevated levels. FEBS Letters. 579: 783-791.

Mirck J, Zalesny RS. 2015. Mini-review of knowledge gaps in salt tolerance of plants applied to willows and poplars, International Journal of Phytoremediation. 17: 640-650. doi: :10.1080/15226514.2014.950414.

Moreira CS, Alleoni LRF. 2010. Adsorption of $\mathrm{Cd}, \mathrm{Cu}, \mathrm{Ni}$ and $\mathrm{Zn}$ in tropical soils under competitive and non-competitive systems, Scientia Agricola. 67: 301-307. doi: 10.1590/S0103-90162010000300008.

Obata H, Umebayashi M. 1997. Effects of cadmium on mineral nutrient concentrations in plants differing in tolerance for cadmium, Journal of Plant Nutrition. 20: 97-105.

Pál M, Horvath E, Janda T, Paldi E, Szalai G. 2006. Physiological changes and defense mechanisms induced by cadmium stress in maize, Journal of Plant Nutrition and Soil Science. 169: 239-246.

Pajevic S, Borisec M, Nikolic N, Krstic B, Pilipovic A, Orlovic S. 2009. Phytoremediation capacity of poplar (Populus spp.) and willow (Salix spp.) clones in relation to photosynthesis, Archives of Biological Sciences. 61: 239-247.

Papoyan A, Kochian LV. 2004. Identification of Thlaspi caerulescens genes that may be involved in heavy metal hyperaccumulation and tolerance. Characterization of a novel heavy metal transporting ATPase, Plant Physiology. 136: 3814-3823. doi: pp.104.044503.

Papoyan A, Piñeros M, Kochian LV. 2007. Plant $\mathrm{Cd}^{2+}$ and $\mathrm{Zn}^{2+}$ status effects on root and shoot heavy metal accumulation in Thlaspi caerulescens, New Phytologist. 175: 51-58. doi: 10.1111/j.1469-8137.2007.02073.x.

Pilon-Smits E. 2005. Phytoremediation, Annu. Rev. Plant Biol. 56, 15-39. 

and $P . \times$ canescens, two poplar species that differ in stress tolerance, New Forest. 44: 13-22.

Pulford ID, Watson C. 2003. Phytoremediation of heavy metal-contaminated land by trees A review, Environment International. 29: 529-540.

Rafati M, Khorasani N, Moattar F, Shirvany A, Moraghebi F, Hosseinzadeh S. 2011. Phytoremediation potential of Populus alba and Morus alba for cadmium, chromuim and nickel absorption from polluted soil, International Journal of Environmental Research. 5: 961970 .

900

901

902

903

904

905

906

Reeves RD. 2006. Hyperaccumulation of trace elements by plants. In: Morel JL, Echevarria G, Goncharova N, eds. Phytoremediation of Metal-contaminated Soils. Netherlands: Springer, $25-52$.

Robinson BH, Banuelos G, Conesa HM, Evangelou MWH, Schulin R. 2009. The phytomanagement of trace elements in soil, Critical Reviews in Plant Sciences. 28: 240-266.

Romeo S, Francini A, Ariani A, Sebastiani L. 2014. Phytoremediation of Zn: Identify the diverging resistance, uptake and biomass production behaviours of poplar clones under high zinc stress, Water, Air and Soil Pollution. 225: 1-12.

910

911

912

913

914

915

916

Rowell DL.1994. Soil Science: Methods and Applications. Essex: Longman Group UK Ltd.

Sanita di Toppi L, Gabbrielli R. 1999. Response to cadmium in higher plants, Environmental and Experimental Botany. 41: 105-130.

Saraswat S, Rai JPN. 2009. Chemistry and ecology phytoextraction potential of six plant species grown in multimetal contaminated soil, Chemistry and Ecology. 25: 1-11. doi: $10.1080 / 02757540802657185$.

Sarwar N, Imran M, Shaheen MR. et al. 2017. Phytoremediation strategies for soils contaminated with heavy metals: Modifications and future perspectives. Chemosphere. 171: 710-721.

Schreiber L, Hartmann K, Skrabs M, Zeier J. 1999. Apoplastic barriers in roots: chemical composition of endodermal and hypodermal cell walls, Journal of Experimental Botany. 50: 1267-1280. doi: 10.1093/jxb/50.337.1267.

Sebastiani L, Scebba F, Tognetti R. 2004. Heavy metal accumulation and growth responses in poplar clones Eridano (Populus deltoides $\times$ maximowiczii) and I-214 $(P . \times$ euramericana) exposed to industrial waste, Environmental and Experimental Botany. 52: 79-88. doi: http://dx.doi.org/10.1016/j.envexpbot.2004.01.003.

Sergeant K, Kieffer P, Dommes J, Hausman JF, Renaut J. 2014. Proteomic changes in leaves of poplar exposed to cadmium and low-temperature, Environmental and Experimental Botany. 106: 112-123.

Sharma SS, Dietz KJ, Mimura T. 2016. Vacuolar compartmentalization as indispensable component of heavy metal detoxification in plants. Plant, Cell and Environment. 39: 1112- 
Shim D, Kim S, Choi, Y. et al. 2013. Transgenic poplar trees expressing yeast cadmium factor 1 exhibit the characteristics necessary for the phytoremediation of mine tailing soil, Chemosphere. 90: 1478-1486.

Smolders E, Mertens J. 2013. Cadmium. In: Alloway BJ, ed. Heavy Metals in Soils, 3rd edn. Netherlands: Springer, 283-311.

Takahashi R, Bashir K, Ishimaru Y, Nishizawa NK, Nakanishi H. 2012. The role of heavymetal ATPases, HMAs, in zinc and cadmium transport in rice. Plant Signaling and Behaviour. 7: $1605-1607$.

Todeschini V, Lingua G, D'Agostino G, Carniato F, Roccotiello E, Berta G. 2011. Effects of high zinc concentration on poplar leaves: A morphological and biochemical study, Environmental and Experimental Botany. 71: 50-56. doi: http://dx.doi.org/10.1016/j.envexpbot.2010.10.018.

Tran TA, Popova LP. 2013. Functions and toxicity of cadmium in plants: Recent advances and future prospects, Turkish Journal of Botany. 37: 1-13. doi: 10.3906/bot-1112-16.

Tuskan GA, DiFazio SP, Jansson S. et al. 2006. The genome of black cottonwood, Populus trichocarpa (Torr. \& Gray). Science. 313: 1596-1604.

Tylova E, Peckova E, Blascheova Z, Soukoup A. 2017. Casparian bands and suberin lamellae in exodermis of lateral roots: an important trait of root systems response to abiotic stress factors. Annals of Botany. 120: 71-85.

Verbruggen N, Hermans C, Schat H. 2009. Mechanisms to cope with arsenic or cadmium excess in plants, Current Opinion in Plant Biology. 12: 364-372. doi: http://dx.doi.org/10.1016/j.pbi.2009.05.001.

White PJ. 2001. The pathways of calcium movement to the xylem, Journal of Experimental Botany. 52: 891-899. doi: 10.1093/jexbot/52.358.891.

Ye J, Coulouris G, Zaretskaya I, Cutcutache I, Rozen S, Madden TL. 2012. PrimerBLAST: A tool to design target-specific primers for polymerase chain reaction. $B C M$ Bioinformatics. 13: 134. doi: 10.1186/1471-2105-13-134.

Zacchini M, Pietrini F, Mugnozza GS, Iori V, Pietrosanti L, Massacci A. 2009. Metal tolerance, accumulation and translocation in poplar and willow clones treated with cadmium in hydroponics, Water, Air and Soil Pollution. 197: 23-34. doi: 10.1007/s11270-008-9788-7.

Zar JH. 2010. Biostatistical analysis, 5th edn. New Jersey: Prentice Hall. 


\section{FIGURE CAPTIONS}

996 Fig. 1 - Phytotoxic effects of $\mathrm{Cd}$ and $\mathrm{Zn}$ in Populus trichocarpa at different soil concentrations, after five weeks of exposure.

Fig. 2 - Root scans of Populus trichocarpa exposed to different $\mathrm{Cd}$ and $\mathrm{Zn}$ concentrations during five weeks. Images were used for length, area, volume and diameter analyses.

Fig. 3 - Toxicity ranks of $P$. trichocarpa exposed to different $\mathrm{Cd}$ and $\mathrm{Zn}$ concentrations. 1003 Symptomatic leaf tissue area (SLTA) was assessed visually and scored from 0 to 5 (each score 1004 represent $20 \%$ of leaf area). Significant differences are represented by different letters by Tukey test $(p<0.05)$ in Cd treatments and Dunn's test $(p<0.05)$ in Zn treatments.

Fig. 4 - $\mathrm{Cd}$ and $\mathrm{Zn}$ concentrations $\left(\mathrm{mg} \mathrm{kg}^{-1}\right)$ in leaves, stems and roots of Populus trichocarpa grown for five weeks in sandy substrate at different $\mathrm{Cd}$ or $\mathrm{Zn}$ doses. Error bars indicate standard error of the mean $(n=4)$. Different letters correspond to significant differences between doses applied (Cd: Tukey test, $p<0.05$; Zn: Dunn's test, $p<0.05$ ). To better visualise the complete data, $\mathrm{x}$ axis was set in log scale and breaks were added to both axes. Dotted lines indicate gaps between axis breaks.

1013

1014 Fig. 5 - Transcript levels of the PtHMA4 gene in roots and leaves of P. trichocarpa after 1015 growing for eight weeks under $\mathrm{Cd}\left(81 \mathrm{mg} \mathrm{kg}^{-1}\right)$ or $\mathrm{Zn}\left(300 \mathrm{mg} \mathrm{kg}^{-1}\right)$ stress, and without any 1016 metal addition (Control). The mRNA levels were quantified by real-time qPCR and normalised 1017 in relation to Ubiquitin (UBQ) expression. Different letters represent significant differences 1018 among treatments, determined by Tukey test after ANOVA ( $p=0.0167)$. There were no 1019 differences among treatments in leaf tissues. 
1021 Fig. 6 - Concentrations of $\mathrm{Cd}$ and $\mathrm{Zn}$ in leaves, stems and roots of Populus trichocarpa exposed 1022 to different metal combinations: $27 \mathrm{mg} \mathrm{kg}^{-1} \mathrm{Cd}$, 90 or $270 \mathrm{mg} \mathrm{kg}^{-1} \mathrm{Zn}$. Different letters 1023 correspond to significant differences among treatments for the same plant tissue, Tukey test $(p$ $1024<0.05)$ in the top figure and Dunn's test $(p<0.05)$ in the bottom figure. 
Table S1. Root morphologic parameters, leaf transpiration (E) and stomatal conductance (gs) of Populus trichocarpa exposed to different $\mathrm{Cd}$ and $\mathrm{Zn}$ concentrations for five weeks.

\begin{tabular}{rcccccc}
\hline Metal & Length & $\begin{array}{c}\text { Projected } \\
\text { area }\end{array}$ & $\begin{array}{c}\text { Average } \\
\text { diameter }\end{array}$ & $\begin{array}{c}\text { Root } \\
\text { volume }\end{array}$ & E & gs \\
\hline $\boldsymbol{C d}\left(\boldsymbol{m g} \boldsymbol{k g}^{-1}\right)$ & $--\mathrm{cm} \mathrm{--}$ & $--\mathrm{cm}^{2}--$ & $--\mathrm{mm}--$ & $--\mathrm{cm}^{3}--$ & $\mathrm{mmol} \mathrm{m}^{-2} \mathrm{~s}^{-1}$ & $\mathrm{~mol} \mathrm{~m}^{-2} \mathrm{~s}^{-1}$ \\
Control & $1963 \mathrm{a}$ & $100.8 \mathrm{a}$ & $0.52 \mathrm{a}$ & $4.08 \mathrm{a}$ & $2.65 \mathrm{a}$ & $0.08 \mathrm{a}$ \\
1 & $2228 \mathrm{a}$ & $108.0 \mathrm{a}$ & $0.49 \mathrm{a}$ & $4.15 \mathrm{a}$ & $2.81 \mathrm{a}$ & $0.08 \mathrm{a}$ \\
3 & $2080 \mathrm{a}$ & $100.1 \mathrm{a}$ & $0.48 \mathrm{a}$ & $3.83 \mathrm{a}$ & $2.60 \mathrm{a}$ & $0.08 \mathrm{a}$ \\
9 & $1980 \mathrm{a}$ & $95.3 \mathrm{a}$ & $0.49 \mathrm{a}$ & $3.65 \mathrm{ab}$ & $2.67 \mathrm{a}$ & $0.08 \mathrm{a}$ \\
27 & $2028 \mathrm{a}$ & $101.4 \mathrm{a}$ & $0.50 \mathrm{a}$ & $4.02 \mathrm{a}$ & $2.50 \mathrm{a}$ & $0.07 \mathrm{a}$ \\
81 & $2002 \mathrm{a}$ & $86.8 \mathrm{a}$ & $0.43 \mathrm{ab}$ & $2.97 \mathrm{ab}$ & $2.40 \mathrm{a}$ & $0.06 \mathrm{a}$ \\
243 & $233 \mathrm{~b}$ & $9.3 \mathrm{~b}$ & $0.37 \mathrm{~b}$ & $0.37 \mathrm{~b}$ & $0.48 \mathrm{~b}$ & $0.01 \mathrm{~b}$ \\
$\mathbf{Z n}\left(\boldsymbol{m g} \boldsymbol{k g}^{-1}\right)$ & & & & & & \\
Control & $2106 \mathrm{a}$ & $100.8 \mathrm{a}$ & $0.52 \mathrm{a}$ & $4.43 \mathrm{a}$ & $2.89 \mathrm{a}$ & $0.08 \mathrm{a}$ \\
30 & $2046 \mathrm{a}$ & $92.9 \mathrm{a}$ & $0.49 \mathrm{ab}$ & $3.87 \mathrm{a}$ & $2.81 \mathrm{a}$ & $0.08 \mathrm{a}$ \\
90 & $1966 \mathrm{a}$ & $93.5 \mathrm{a}$ & $0.49 \mathrm{ab}$ & $3.81 \mathrm{a}$ & $2.76 \mathrm{a}$ & $0.08 \mathrm{a}$ \\
270 & $1833 \mathrm{ab}$ & $63.4 \mathrm{ab}$ & $0.47 \mathrm{abc}$ & $2.88 \mathrm{ab}$ & $2.47 \mathrm{a}$ & $0.06 \mathrm{a}$ \\
810 & $763 \mathrm{bc}$ & $22.6 \mathrm{bc}$ & $0.35 \mathrm{~cd}$ & $0.85 \mathrm{bc}$ & $1.94 \mathrm{a}$ & $0.05 \mathrm{a}$ \\
2430 & $333 \mathrm{c}$ & $13.1 \mathrm{c}$ & $0.41 \mathrm{bcd}$ & $0.40 \mathrm{c}$ & $\mathrm{x}$ & $\mathrm{x}$ \\
7290 & $363 \mathrm{c}$ & $10.5 \mathrm{c}$ & $0.33 \mathrm{~d}$ & $0.34 \mathrm{c}$ & $\mathrm{x}$ & $\mathrm{x}$ \\
\hline Significant & & & & & \\
\hline
\end{tabular}

Significant differences among treatments (for each metal) are represented by different letters.

Cd treatments: Tukey test: $p<0.05, \mathrm{n}=4$;

Zn treatments: Dunn test, $p<0.05, \mathrm{n}=3$.

x's represent dead leaves and measurements were not recorded.

1027

1028

1029

1030

Table S2. Spearman correlation $\left(\mathrm{r}_{\mathrm{s}}\right)$ matrix between 14 different variables from Populus trichocarpa grown under different $\mathrm{Cd}$ concentrations. Variables were considered monotonic correlated for $p<0.05$. 


\begin{tabular}{|c|c|c|c|c|c|c|c|c|c|c|c|c|c|c|}
\hline Variables & 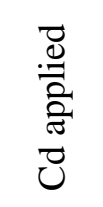 & 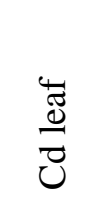 & ت্: & $\begin{array}{l}E \\
\frac{\Xi}{\omega} \\
\vec{U}\end{array}$ & 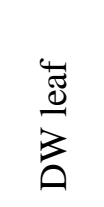 & 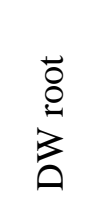 & $\begin{array}{l}E \\
\frac{\Xi}{0} \\
z \\
0\end{array}$ & 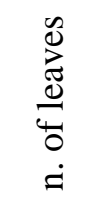 & 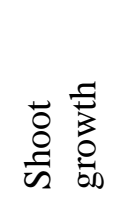 & 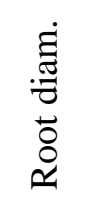 & 피 & Do & 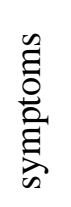 & $\frac{\pi}{2}$ \\
\hline Cd applied & 1 & & & & & & & & & & & & & \\
\hline Cd leaf & 0.94 & 1 & & & & & & & & & & & & \\
\hline Cd root & 0.98 & 0.93 & 1 & & & & & & & & & & & \\
\hline Cd stem & 0.96 & 0.98 & 0.96 & 1 & & & & & & & & & & \\
\hline DW leaf & -0.72 & -0.73 & -0.68 & -0.71 & 1 & & & & & & & & & \\
\hline DW root & -0.60 & -0.68 & -0.58 & -0.65 & 0.83 & 1 & & & & & & & & \\
\hline DW stem & -0.64 & -0.69 & -0.61 & -0.67 & 0.82 & 0.76 & 1 & & & & & & & \\
\hline n. of leaves & -0.61 & -0.52 & -0.58 & -0.51 & 0.60 & $\mathrm{~ns}^{*}$ & 0.45 & 1 & & & & & & \\
\hline $\begin{array}{l}\text { Shoot } \\
\text { growth }\end{array}$ & -0.71 & -0.63 & -0.68 & -0.64 & 0.76 & 0.51 & 0.67 & 0.88 & 1 & & & & & \\
\hline Root diam. & -0.54 & -0.53 & -0.53 & -0.51 & 0.66 & 0.73 & 0.52 & 0.46 & 0.57 & 1 & & & & \\
\hline$E$ & -0.48 & ns & -0.47 & -0.40 & 0.61 & ns & 0.46 & 0.77 & 0.84 & 0.47 & 1 & & & \\
\hline$g s$ & -0.61 & -0.47 & -0.61 & -0.51 & 0.50 & ns & 0.41 & 0.73 & 0.76 & 0.41 & 0.81 & 1 & & \\
\hline symptoms & 0.77 & 0.66 & 0.76 & 0.72 & -0.39 & $\mathrm{~ns}$ & -0.48 & -0.50 & -0.46 & $\mathrm{~ns}$ & $\mathrm{~ns}$ & -0.52 & 1 & \\
\hline$p H$ & $\mathrm{~ns}$ & -0.43 & ns & -0.39 & 0.40 & 0.53 & ns & $\mathrm{ns}$ & ns & $\mathrm{ns}$ & $\mathrm{ns}$ & $\mathrm{ns}$ & ns & 1 \\
\hline
\end{tabular}

Cd applied: Cd solutions applied in the substrate $\left(0 ; 1 ; 3 ; 9 ; 27 ; 81 ; 243 \mathrm{mg} \mathrm{kg}^{-1}\right)$;

Cd leaf, stem, root: $\mathrm{Cd}$ concentration in plant tissues;

DW: dry weight;

n. of leaves: number of expanded leaves at harvest;

Shoot growth: difference (in $\mathrm{cm}$ ) of shoot height before and after Cd treatment;

Root diam.: mean root diameter;

E: leaf transpiration;

gs: stomatal conductance;

symptoms: toxicity symptoms in leaves at harvest;

$\mathrm{pH}$ : substrate $\mathrm{pH}$ after harvest.

1031

1032

Table S3. Spearman correlation $\left(\mathrm{r}_{\mathrm{s}}\right)$ matrix between 14 different variables from Populus trichocarpa grown under different $\mathrm{Zn}$ concentrations. Variables were considered monotonic correlated for $p<0.05$. 


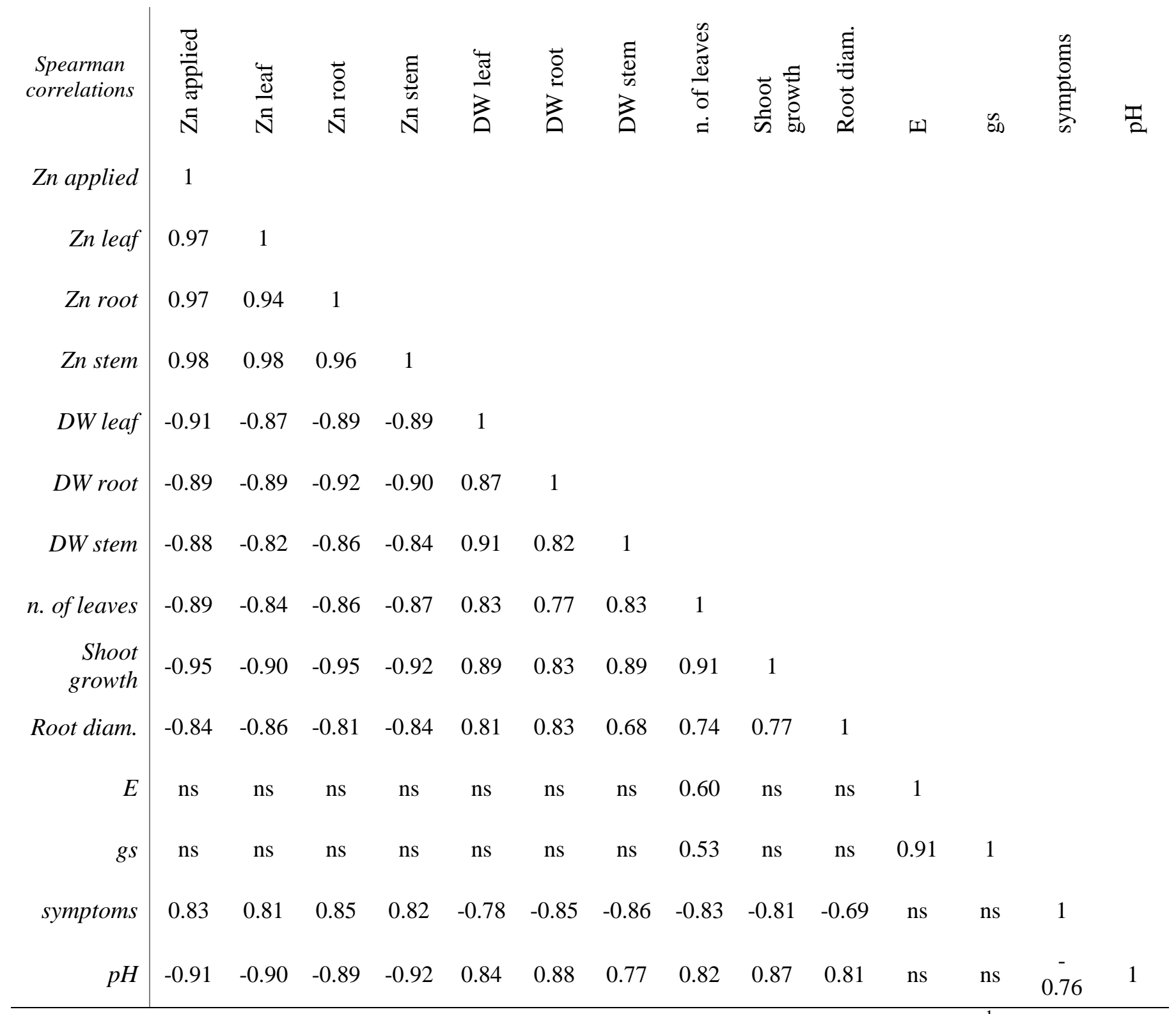

${ }^{\mathrm{a}} \mathrm{Zn}$ applied: $\mathrm{Zn}$ solutions applied in the substrate $\left(0 ; 30 ; 90 ; 270 ; 810 ; 2430 ; 7290 \mathrm{mg} \mathrm{kg}^{-1}\right)$; $\mathrm{Zn}$ leaf, stem, root: $\mathrm{Zn}$ concentration in plant tissues;

DW: dry weight;

n. of leaves: number of expanded leaves at harvest;

Shoot growth: difference (in $\mathrm{cm}$ ) of shoot height before and after $\mathrm{Zn}$ treatment;

Root diam.: mean root diameter;

E: leaf transpiration;

gs: stomatal conductance;

symptoms: toxicity symptoms in leaves at harvest;

$\mathrm{pH}$ : substrate $\mathrm{pH}$ after harvest.

1033

1034 
Table S4. Cadmium concentration, total uptake, translocation factor (Tf: roots-to-leaves) and bioconcentration factor (BCF) in Populus trichocarpa 'Trichobel' grown for five weeks under different Cd doses.

\begin{tabular}{|c|c|c|c|c|c|c|c|}
\hline \multirow[t]{2}{*}{$\begin{array}{c}\mathrm{Cd} \\
\left(\mathrm{mg} \mathrm{kg}^{-1}\right)\end{array}$} & \multicolumn{3}{|c|}{$\begin{array}{l}\text { Cd concentration } \\
\qquad\left(\mathrm{mg} \mathrm{kg}^{-1}\right)\end{array}$} & \multirow[t]{2}{*}{$\begin{array}{l}\text { Cd uptake } \\
\left(\mu \text { plant }^{-1}\right)\end{array}$} & \multirow[t]{2}{*}{$\mathrm{T} f$} & \multicolumn{2}{|c|}{$\mathrm{BCF}$} \\
\hline & Leaves & Stems & Roots & & & Leaf & Root \\
\hline Control & $0.5 \pm 0.1 \mathrm{aA}$ & $1.4 \pm 0.3 \mathrm{aA}$ & $2.5 \pm 0.4 \mathrm{aB}$ & $3.2 \pm 0.3$ & 20 & --- & --- \\
\hline 1 & $2.6 \pm 0.1 \mathrm{bA}$ & $3.4 \pm 0.4 \mathrm{bB}$ & $14.4 \pm 2.7 b C$ & $14.8 \pm 3.1$ & 18 & 2.6 & 14.4 \\
\hline 3 & $6.2 \pm 0.3 \mathrm{cA}$ & $8.30 \pm 0.8 \mathrm{cA}$ & $35.1 \pm 4.4 \mathrm{cB}$ & $31.0 \pm 5.2$ & 18 & 2.1 & 11.7 \\
\hline 9 & $42.9 \pm 4.4 \mathrm{dA}$ & $41.1 \pm 7.1 \mathrm{dA}$ & $105 \pm 18 \mathrm{dA}$ & $119 \pm 11$ & 41 & 4.8 & 11.7 \\
\hline 27 & $42.0 \pm 4.3 \mathrm{dA}$ & $42.6 \pm 7.3 \mathrm{dA}$ & $163 \pm 29 \mathrm{~dB}$ & $167 \pm 22$ & 26 & 1.6 & 6.0 \\
\hline 81 & $53.9 \pm 2.0 \mathrm{dA}$ & $67.4 \pm 9.7 \mathrm{dA}$ & $487 \pm 64 \mathrm{eB}$ & $267 \pm 52$ & 11 & 0.7 & 6.0 \\
\hline 243 & $681 \pm 31$ eA & $434 \pm 98$ eA & $6,537 \pm 816 \mathrm{fB}$ & $629 \pm 157$ & 6 & 2.8 & 47.6 \\
\hline \multicolumn{8}{|c|}{$\begin{array}{l}\text { Different lowercase letters denote significant difference between treatments by Tukey test }(p< \\
0.05) \text {; } \\
\text { Different uppercase letters denote significant differences between plant organs in the same } \\
\text { treatment by Tukey test }(p<0.01) \text {. } \\
T f=(\text { leaf concentration / root concentration }) \times 100 \text {. } \\
\mathrm{BCF}=\text { (plant concentration / soil concentration). }\end{array}$} \\
\hline
\end{tabular}


Table S5. Zinc concentration, total uptake, translocation factor (Tf: roots-to-leaves) and bioconcentration factor (BCF) in Populus trichocarpa 'Trichobel' grown for five weeks under different $\mathrm{Zn}$ doses.

\begin{tabular}{|c|c|c|c|c|c|c|c|}
\hline \multirow[t]{2}{*}{$\begin{array}{c}\mathrm{Zn} \\
\left(\mathrm{mg} \mathrm{kg}^{-1}\right)\end{array}$} & \multicolumn{3}{|c|}{$\begin{array}{l}\text { Zn concentration } \\
\qquad\left(\mathrm{g} \mathrm{kg}^{-1}\right)\end{array}$} & \multirow[t]{2}{*}{$\begin{array}{l}\text { Zn uptake } \\
\left(\mathrm{mg} \mathrm{plant}^{-1}\right)\end{array}$} & \multirow[t]{2}{*}{$T f$} & \multicolumn{2}{|c|}{$\mathrm{BCF}$} \\
\hline & Leaves & Stems & Roots & & & Leaf & Root \\
\hline Control & $0.09 \pm 0.01 \mathrm{aB}$ & $0.04 \pm 0.01 \mathrm{aA}$ & $0.2 \pm 0.01 \mathrm{aC}$ & $0.3 \pm 0.01$ & 33 & --- & --- \\
\hline 30 & $0.1 \pm 0.01 \mathrm{aA}$ & $0.3 \pm 0.1 \mathrm{bAB}$ & $0.4 \pm 0.1 \mathrm{aC}$ & $0.5 \pm 0.1$ & 21 & 3.1 & 14.8 \\
\hline 90 & $0.2 \pm 0.02 \mathrm{bA}$ & $0.5 \pm 0.01 \mathrm{bB}$ & $0.6 \pm 0.1 \mathrm{aB}$ & $0.9 \pm 0.1$ & 40 & 2.6 & 6.5 \\
\hline 270 & $0.7 \pm 0.1 \mathrm{cA}$ & $0.8 \pm 0.1 \mathrm{bcA}$ & $2.5 \pm 0.9 \mathrm{bA}$ & $2.0 \pm 0.2$ & 26 & 2.4 & 9.3 \\
\hline 810 & $1.5 \pm 0.1 \mathrm{cdA}$ & $1.9 \pm 0.2 \mathrm{cdAB}$ & $5.6 \pm 1.3 \mathrm{bcB}$ & $2.5 \pm 0.5$ & 27 & 1.9 & 6.9 \\
\hline 2,430 & $2.2 \pm 0.4 \mathrm{dA}$ & $4.8 \pm 1.1 \mathrm{dA}$ & $10.1 \pm 1.5 \mathrm{cdB}$ & $3.5 \pm 1.1$ & 22 & 0.9 & 4.2 \\
\hline 7,290 & $12.8 \pm 3.5 \mathrm{eA}$ & $24.3 \pm 4.2 \mathrm{eA}$ & $21.5 \pm 5.3 \mathrm{dA}$ & $17.9 \pm 2.2$ & 59 & 1.7 & 2.9 \\
\hline
\end{tabular}

Different lowercase letters denote significant difference between treatments by Dunn test $(p<$ $0.05)$

Different uppercase letters denote significant differences between plant organs in the same treatment by Dunn test $(p<0.01)$.

$T f=$ (leaf concentration / root concentration $) \times 100$.

1057

$\mathrm{BCF}=$ (plant concentration / soil concentration). 